\title{
PREDAÇÃO DE ANIMAIS DOMÉSTICOS E PLANTAÇÕES NO ENTORNO DO PARQUE NACIONAL DO IGUAÇU (PR) - Análise da Percepção de Fazendeiros e Alternativas de Manejo
}

\section{LUCILA MANZATTI}

Ecóloga

Orientador: Prof. Dr. Álvaro Fernando de Almeida

Dissertação apresentada à Escola Superior de Agricultura "Luiz de Queiroz", Universidade de São Paulo, para obtenção do título de Mestre em Ciências Florestais.

\author{
PIRACICABA \\ Estado de São Paulo - Brasil \\ Dezembro - 1999
}


Para Diadorim, com a esperança que possa ver Iguaçu com suas onças, queixadas, quatis, capivaras,... 


\section{AGRADECIMENTOS}

- Prof. Álvaro Fernando de Almeida, pela oportunidade e confiança.

- José Roberto Manna de Deus, Anderson Pagoto e João Valsechi do Amaral pelo auxílio na coleta de dados.

- Peter Crawshaw por me apresentar o Parque Nacional do Iguaçu, pelo aprendizado e estímulo constantes.

- Prof. Luiz Carlos E. Rodriguez e Prof. Luciano Verdade, pessoas que admiro e que gentilmente fizeram diversas sugestões ao trabalho.

- Minha família pelo amor, apoio e incentivos: Zé Roberto, Luci, Moacyr, Marli, Sinval, Paulo, Mari, Felipe, Paula e Gabi.

- Maria de Fátima de Oliveira, Romildo Campello, Mônica Nishie, Celina Umezaki, Carlos Broering, Catarina Xavier da Silva, Amália Manna de Deus e Júlio Voltolini, pela amizade, atenção e paciência, especialmente na última fase deste trabalho;

- A CAPES pela concessão da bolsa de Mestrado.

-Secretários e técnicos das Secretarias Municipais de Agricultura dos municípios de entorno do Parque Nacional do Iguaçu, pelas informações valiosas.

- Aos 60 proprietários que participaram desta pesquisa pela confiança, atenção e pelas horas agradáveis de conversa ao lado de um dos lugares mais lindos deste país. 


\section{SUMÁRIO}

Página

LISTA DE FIGURAS...........................................................................

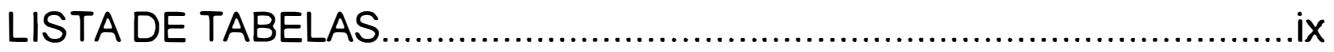

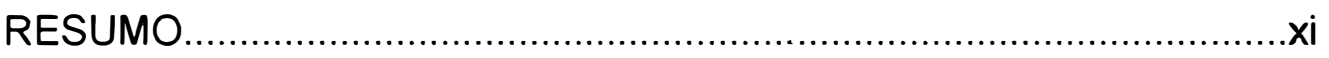

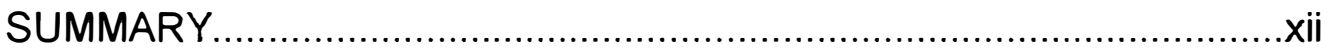

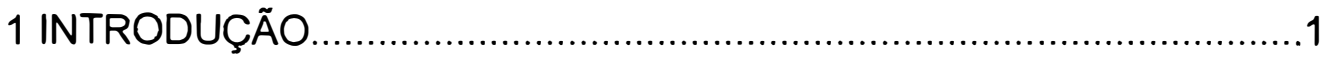

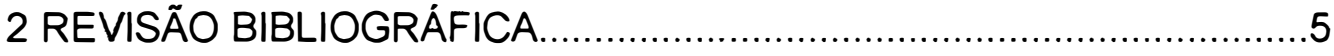

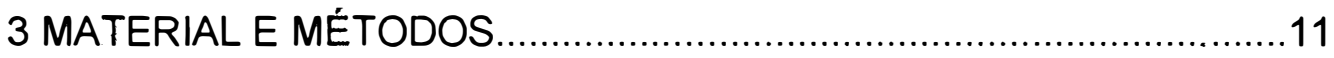

3.1 Parque Nacional do Iguaçu............................................................11

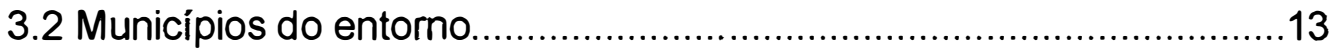

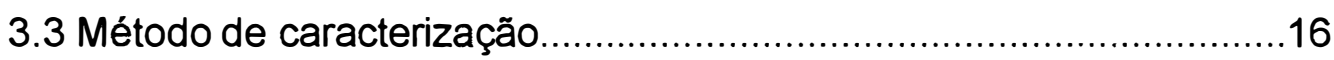

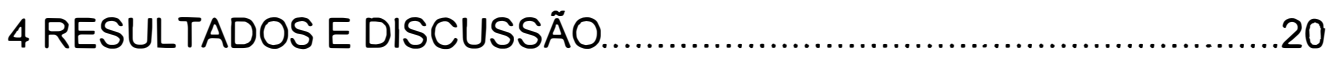

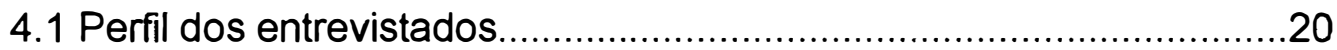

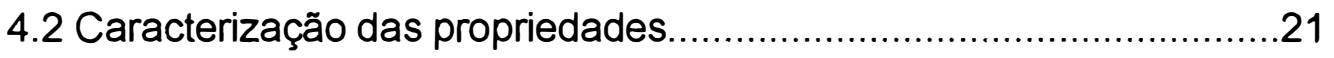

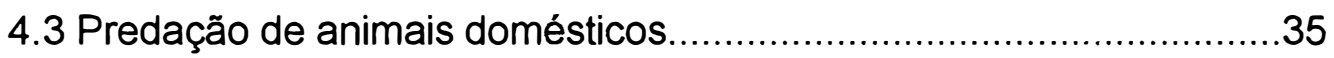

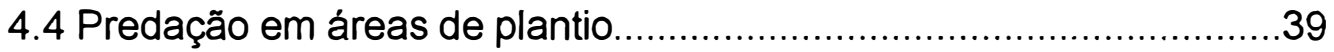

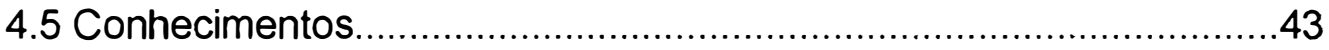

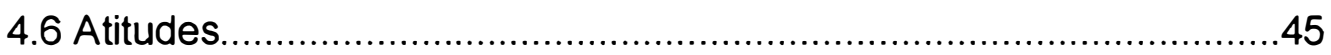

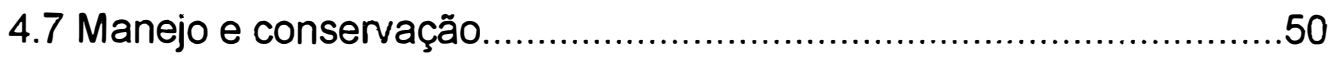

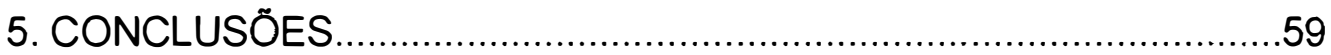

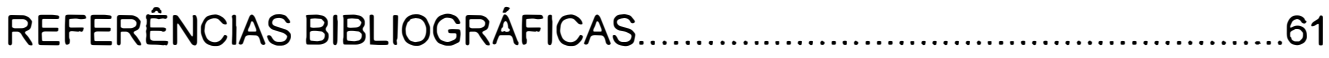

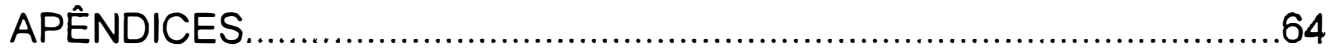




\section{LISTA DE FIGURAS}

Página

1 Vista parcial do Parque Nacional do Iguaçu.........................................11

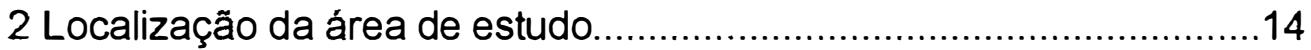

3 Vista parcial de propriedade do entomo

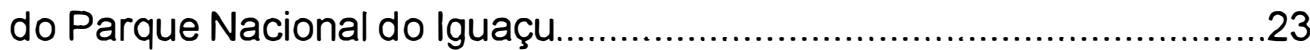

4 Vista parcial de propriedade do entomo

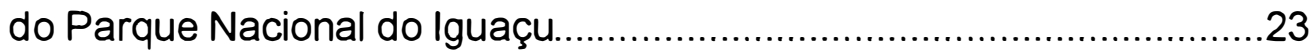

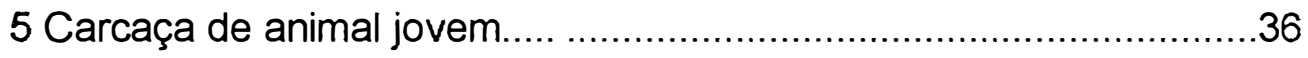

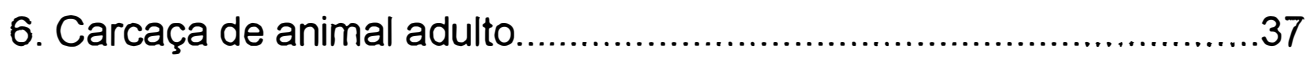




\section{LISTA DE TABELAS}

Página

1 Caracterização dos municipios do entorno

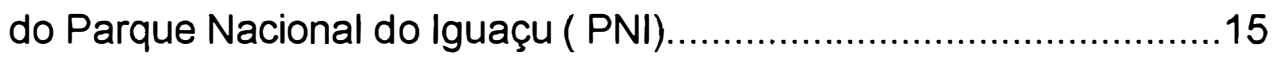

2 Número de propriedades adjacentes ao PNI ....................................21

3 Categorias de tamanho das propriedades amostradas ......................22

4 Número de animais domésticos e tipo de manejo adotado nas propriedades de Foz do Iguaçu....................................25

5 Número de animais domésticos e tipo de manejo adotado nas propriedades de São Miguel do Iguaçu ..........................26

6 Número de animais domésticos e tipo de manejo adotado nas propriedades de Serranópolis do Iguaçu.........................27

7 Número de animais domésticos e tipo de manejo adotado nas propriedades de Matelândia............................................28

8 Número de animais domésticos e tipo de manejo adotado nas propriedades de Céu Azul.............................................29

9 Número de animais domésticos e tipo de manejo adotado nas propriedades de Santa Terezinha do Itaipu......................30

10 Número de animais domésticos e tipo de manejo adotado nas propriedades de Santa Tereza

11 Número de animais domésticos e tipo de manejo adotado nas propriedades de Lindoeste.

12 Número de animais domésticos e tipo de manejo adotado nas propriedades de Capitâo Leônidas Marques 


\section{LISTA DE TABELAS}

\section{Página}

13 Número de animais domésticos e tipo de manejo adotado nas propriedades de Capanema. .35

14 Número de animais predados por mamíferos silvestres 37

15 Caracterização da predação em áreas cultivadas por mamíferos silvestres

16 Conhecimento dos proprietários sobre animais silvestres por município

17 Conhecimento dos proprietários por espécie de mamifero silvestre .45

18 Atitudes dos proprietários com relação a fauna. 


\title{
PREDAÇÃO DE ANIMAIS DOMÉSTICOS E PLANTAÇÕES NO ENTORNO DO PARQUE NACIONAL DO IGUAÇU (PR) - Análise da Percepção de Fazendeiros e Alternativas de Manejo.
}

\author{
Autora: LUCILA MANZATTI \\ Orientador: Prof. ÁLVARO FERNANDO DE ALMEIDA
}

\section{RESUMO}

A percepção de fazendeiros com relação à predação de animais domésticos e plantações por mamíferos silvestres foi analisada através de um levantamento em 60 propriedades, no entorno do Parque Nacional do Iguaçu, Paraná. As informações fornecidas corresponderam ao período entre janeiro1995 e janeiro de 1999. Cerca de $80 \%$ dos entrevistados registraram perdas de animais domésticos em 66 ocasiões. A onça- pintada (Panthera onca) e a onça-parda (Puma concolor) estiveram envolvidas em $62 \%$ dos eventos. Trinta e um proprietários tiveram seus cultivos atacados em 42 ocasiões, sendo que cinco espécies foram responsáveis por $86 \%$ dos eventos: queixada (Tayassu pecari), capivara (Hidrochoerus hidrochaeris), quati (Nasua nasua), cateto (Tayassu tajacu) e tatu (Dasypus novemcinctus). De forma geral, os prejuízos causados nos cultivos são considerados irrelevantes, assim como sobre animais domésticos de baixo valor comercial. Os proprietários apresentaram conhecimento básico sobre as principais espécies envolvidas, assim como atitudes positivas. Existe, porém, uma tendência ao 
desenvolvimento de atitudes negativas para com os grandes felinos, uma vez que as perdas associadas a eles representam fontes de investimentos $\mathrm{e}$ rendimentos, como por exemplo gado e ovelhas $A$ conservação de mamíferos silvestres, no entorno do Parque Nacional do Iguaçu depende do apoio dos proprietários na solução dos conflitos de predação. Para tanto, torna-se necessário o desenvolvimento de programas de extensão e educação ambiental que disponibilizem conhecimentos técnico sobre métodos preventivos e incluam componentes cognitivos e afetivos. 


\title{
PREDATION OF DOMESTIC LIVESTOCK IN THE BORDER OF IGUAÇU NATIONAL PARK -An analysis of perception of farmers and management practices
}

\author{
Author: LUCILA MANZATTI \\ Advisor: Prof. Dr. ÁLVARO FERNANDO DE ALMEIDA
}

SUMMARY

Perception of farmers toward wild mammals causing predation of domestic livestock and crops were investigated by a questionnaire survey of 60 properties in the border of Iguaçu National Park, Parana State, Brazil. Data collected relates to the period of January 1995 to January 1999. Approximately $80 \%$ of farmers registered losses of domestic livestock in 66 ocasions. The jaguar (Panthera onca) and puma (Puma concolor) accounted for $62 \%$ of predation. Thirty one farmers had their crops damaged in 42 occasions with 5 species causing damages to $86 \%$ of all situations: white-lipped-peccary (Tayassu pecari), capybara (Hidrochoerus hidrochaeris), coati (Nasua nasua), peccari (Tayassu tajacu) and armadillo (Dasypus novemcinctus). In general aspects losses caused by damage on crops were considered irrelevant as well as to domestic animals of low commercial value. Farmers showed basic knowledge on most species involved in this study as well positive attitude. However there is a tendency to the development of negative attitude toward big 
cats, since their behaviour produced losses to source of investments and income i.e. cattle and sheep. Wild mammals conservation in the border of Iguaçu National Park depends on support of farmers in solving conflicts over the cases of predation. It is fundamental the development of an environmental education program that makes technnical knowledge available to all farmers mainly related to prevention of such problems including cognitive and affective components. 


\section{INTRODUÇÃO}

A partir da Revolução Industrial, o rápido crescimento da população humana tem causado uma maior demanda sobre recursos naturais. Grandes áreas têm sido ocupadas e transformadas em lavouras e pastagens, visando o fornecimento de alimentos. Neste contexto, a maior parte da fauna e flora nativas encontram-se restritas, principalmente, às áreas legalmente protegidas e através das unidades de conservação.

No sudoeste do Brasil esta situação está exemplificada pelo Parque Nacional do Iguaçu, um fragmento florestal cercado por intensas atividades humanas nas áreas adjacentes aos seus limites. Situado em uma região de solos ricos para agricultura, o entorno do Parque Nacional é caracterizado por extensas plantações, principalmente, de soja, milho, trigo e pastagens. Apesar desta proximidade, o Parque ainda abriga boa parte de sua fauna original, incluindo grandes predadores, como a onça-pintada (Panthera onca) e a onça-parda (Puma concolor), e ungulados como os porcos-do-mato (Tayassu pecari e $T$. tajacu) e a anta (Tapirus terrestris) (Crawshaw Jr., 1995).

O Parque Nacional do Iguaçu representa, atualmente, $80 \%$ do que restou da floresta subtropical que cobria o estado do Paraná (IBDF, 1981). Em 1994, o Instituto Brasileiro do Meio Ambiente e dos Recursos Naturais Renováveis - IBAMA, elaborou para o Parque um Plano de Ação Emergencial, tendo em vista a defasagem do Plano de Manejo do Parque e 
a necessidade de alternativas para o gerenciamento da unidade. Entre os principais problemas citados no Plano de Ação Emergencial estão as relações do Parque com o seu entorno. A exploração ilegal dos recursos naturais do Parque, o emprego de práticas não conservacionistas pelos produtores vizinhos, o conflito entre proprietários e a fauna e a falta de entendimento e valorização do Parque estão entre as prioridades a serem trabalhadas e resolvidas nos próximos anos.

A presença de animais domésticos e as plantações na borda do Parque funcionam como um forte atrativo para os animais silvestres. Janzen (1986) argumenta que a medida que a agricultura se intensifica e moderniza ao redor de uma reserva, as chances de danos causados por animais silvestres nestas áreas aumentam. O Parque Nacional do Iguaçu não foge a esta regra. As invasões de roças, especialmente as de milho, e os ataques a aves domésticas, cachorros, porcos, ovelhas e gado são problemas comuns. Nos últimos anos, a Polícia Florestal e o IBAMA têm recebido várias queixas por parte de fazendeiros e sitiantes, vizinhos ao Parque, relativas a predação de animais silvestres, com prejuizos estimados em alguns casos entre US $\$ 1,100$ e US $\$ 5,400$ (Crawshaw Jr., 1995).

Sem contar com um apoio institucional adequado, a maioria dos proprietários tenta resolver estes problemas por conta própria, eliminando os animais silvestres. Os resultados desta situação têm sido negativos para todas as partes: fazendeiros e sitiantes acumulam prejuizos financeiros, que podem inclusive ser aumentados como resultado de sua interferência inadequada no ambiente, e entram em confronto com a Polícia Florestal. As populações silvestres perdem indivíduos, muitas vezes de espécies altamente ameaçadas de extinção, importantes para a manutenção 
do ecossistema.

Frente a esta situação, o IBAMA criou em 1994 o Centro Nacional de Pesquisa para a Conservação de Predadores Naturais CENAP (Portarias 78/94; $101 / 95$ de 18/12/1995). O principal objetivo do CENAP é elaborar e implementar uma política adequada de manejo e conservação para os predadores naturais. Entre as atividades desenvolvidas pelo CENAP estão o atendimento de denúncias relacionadas com problemas de predação sobre criações de animais domésticos, a manutenção de um banco de dados de ocorrências e a capacitação de pessoal. Os registros de predação no país, ocorridos entre 1986 e 1998, somam 338 casos. Destes, 50 ocorreram no estado do Paraná. É sabido, porém, que estes totais encontram-se subestimados, uma vez que dependem do fornecimento de informações dos funcionários das superintendências regionais do IBAMA.

Possiveis alternativas para estes problemas envolvem considerações de ordem biológica, social, econômica e política (Howard, 1974 e Schaller, 1996) e requerem a participação tanto dos órgãos governamentais, responsáveis pelo manejo de vida silvestre, como dos proprietários particulares de terras. Desta forma, é necessário conhecer não somente a localização e extensão dos prejuízos causados, mas também como os diferentes tipos de proprietários percebem o dano e a presença destes animais em suas terras.

Este trabalho analisa a percepção de proprietários vizinhos ao Parque Nacional do Iguaçu sobre a predação de mamíferos silvestres nas áreas de cultivo e nos animais domésticos. Aqui é utilizada a definição de predador no seu sentido amplo, envolvendo carnivoros e 
herbivoros. Mais específicamente, utiliza-se da definição econômica para o termo, dada por Cravino (1992, citado por Dotto, 1997), tratando o predador como um animal que afeta os interesses econômicos de uma propriedade. 


\section{REVISÃO BIBLIOGRÁFICA}

Na América do Norte, Europa, África e Austrália, há várias décadas, existem agências e departamentos governamentais que tratam de questões relacionadas à vida silvestre, tais como o "Fish and Wildlife Service" dos Estados Unidos, o "Parks Canada", no Canadá, o "Italian Forestry Service", na Itália, o "Wildlife Ministry" de Botswana e o "Australian National Parks and Wildlife Service" da Australia. Em alguns estados ou províncias destes paises foram criados setores especificos para resolverem conflitos entre animais silvestres e populações humanas, como o "Problem Wildlife Committee of Alberta Agriculture Energy and Natural Resources", do Canadá e o "Vertebrate Pests Committee" da Austrália.

De acordo com Roy e Dorrance (1976), na América do Norte, os principais problemas de predação sobre animais domésticos, incluindo gado, ovelhas, porcos, cavalos, cães e aves, são normalmente causados por ursos (Ursus americanus e $U$. arctos horribilis), linces (Lynx canadensis e Lynx rufus), doninhas (Mustela erminea, M. rixosa, $M$. frenata e $M$. vison), lobo (Canis lupus ), coiote (Canis latrans ) e onça-parda (Puma concolor).

No oeste dos Estados Unidos, por exemplo, o coiote é considerado como o principal predador de ovelhas (Robel et al., 1981). Por outro lado, a predação de áreas cultivadas, especialmente os pomares de 
maçãs e os plantios de soja e alfafa, é causada principalmente pelos cervídeos. Nestes casos, os danos costumam ser maiores perto das bordas dos plantios com áreas florestadas. Catetos (Tayassu tajacu) e coiotes são conhecidos por danificarem plantios de melacia e outras suculentas. Entretanto, estes problemas não estão restritos às espécies silvestres nativas. Burros (Eqqus asinus), introduzidos por exploradores espanhóis no século XIV, que se tornaram ferais, competem com o gado por pastagens nos estados da Califórnia, Nevada e Arizona (Bolen and Robinson, 1995).

Conover e Decker (1991) registraram nos Estados Unidos um aumento na incidência de conflitos entre animais silvestres e agricultores nos últimos 30 anos. Possivelmente, em decorrência disto, vários estudos sobre estes aspectos têm sido conduzidos, enfocando não só questões biológicas (Johnson and Griffel, 1982; Till and Knowlton, 1983; Conover,1990), como também políticas e sociais sobre atitudes, percepções e valores de fazendeiros e público em geral com a vida silvestre (Kellert, 1986; Kellert and Clark, 1991; Kellert, 1992 e Reading and Kellert, 1993).

$\mathrm{Na}$ Europa a predação de mamíferos silvestres envolve espécies como o lobo (Canis lupus), o urso-marrom (Ursus arctos) e o lince (Lynx lynx) (Boman, 1995). No estudo conduzido por Cozza et al. (1996) no centro da Itália, a maioria dos casos de predação de cabras, ovelhas e eqüinos jovens foram atribuídos ao lobo. Em áreas florestadas da Escócia, na região de Galloway, o veado-vermelho (Cervus elaphus) foi o principal causador de perdas econômicas. Ali o prejuízo foi estimado em cerca de 2 milhões de libras esterlinas por ano. Esta espécie também pode causar prejuizos para fazendeiros danificando plantações na fase de crescimento (Hanley and Sumner, 1995). 
Yom-Tov et al. (1995) estimaram que entre $1,5 \%$ à $1,9 \%$ dos novilhos nascidos em colônias agrícolas localizadas nas Colinas Golan, em Israel, foram mortos por predação. Os chacais (Canis aureus) foram responsáveis por $70 \%$ dos ataques, seguidos pelos cães ferais $(20 \%)$ e lobos (10\%). Só em 1993 os prejuízos foram calculados em cerca de 42 mil dólares. A alta taxa de predação nesta área foi consequência do aumento da população de chacais, resultante da disponibilidade de alimento existente nos depósitos ilegais de lixo dos próprios fazendeiros.

Para regiões do sul da África, Bowland et al. (1992 ) listaram 31 espécies de mamíferos predadores. Entretanto, somente 6 delas são responsáveis pela maior parte das perdas de animais domésticos (leopardo, guepardo, hiena marrom, caracal, chacal-de-dorso-preto e cães domésticos). Pesquisas sobre diferentes predadores que ocorrem em fazendas africanas mostraram que a maioria alimenta-se de roedores e insetos. Nestas regiões os predadores desempenham um papel fundamental em regular o número de roedores, os quais podem alcançar níveis onde os danos às plantações chegam a causar maior perda financeira do que os ataques de mamíferos silvestres aos animais domésticos. Por outro lado, Naughton-Treves (1998) estudando a perda de plantios por mamíferos silvestres em 6 vilas no entorno do Parque Nacional Kibale em Uganda, encontrou que 5 espécies eram responsáveis por $85 \%$ dos eventos: babuínos (Papio cynocephalus), porcos-do-mato (Potamochoerus porcus), Macaco-de-cauda-vermelha (Cercopithecus ascanius), chimpanzés (Pan troglodytes) e elefantes (Loxodonta africana).

Na Austrália a situação é bastante peculiar, uma vez que os animais envolvidos na predação da produção agrícola foram introduzidos por colonizadores europeus. Ali, a lebre-européia (Orytolagus cuniculus), a 
raposa-vermelha (Vulpes vulpes) e o porco (Sus scrofa), cavalo e cabra (Capra hircus) ferais são tratados como pragas. Anualmente são perdidos centenas de milhões de dólares da produção agrícola pela predação por estes animais. Estima-se, por exemplo, que somente no sul da Austrália, as lebres sejam responsáveis pela perda de 17 milhões de dólares por ano na indústria pastoril (Braysher,1993). Segundo Henzel (1991), o controle das populações, nesta área, custa 1,6 milhões de dólares para um benefício de 62 milhões de dólares. Já para os porcos ferais, a estimativa dos custos por danos à produção agrícola é de no mínimo 100 milhões de dólares por ano (Choquenot et al., 1993).

No Brasil, até recentemente, apesar da proximidade de áreas florestadas com populações humanas e de várias referências orais sobre interações de animais silvestres e moradores, poucos registros sistemáticos sobre a predação em áreas agrícolas haviam sido feitos. Da mesma forma, qualquer tipo de assistência à proprietários particulares no sentido de prevenir ou minimizar conflitos era pontual e esporádica.

No noroeste do Rio Grande do Sul, Mahler Jr. \& Oliveira (1996) levantaram dados preliminares sobre os danos causados por mamíferos carnivoros e ungulados nas atividades agropecuárias de propriedades vizinhas ao Parque Estadual do Turvo. Os animais mais frequentemente atacados foram porcos, cães e vacas. Já os cultivos mais atingidos foram os de milho e mandioca, com danos de até $25 \%$ e $13 \%$, respectivamente, da área plantada em cada propriedade amostrada.

Ainda no Rio Grande do Sul, Dotto (1997) registrou que os graxains-do-mato e os graxains-do-campo (Cerdocyon thous e Pseudalopex gymnocercus) eram apontados pelos produtores rurais como os principais 
causadores de morte por predação de cordeiros. Entretanto, os resultados de seu estudo indicaram a ação de outros predadores além dos graxains. De 49 cordeiros predados, $57,1 \%$ foram por graxains, $32,7 \%$ por cães domésticos e $10,2 \%$ por aves. O autor não encontrou evidências suficientes para caracterizar os graxains como predadores importantes de cordeiros, recomendando inclusive, que os mesmos fossem poupados da caça, perseguição $e$ envenenamento, métodos de controle mais frequentemente utilizados na região.

Jacob (1997) registrou a predação por felinos em cerca de 337 cabeças de ovelhas e 11 cabras, em propriedades vizinhas ao Parque Nacional da Serra da Capivara, no Piauí. O manejo extensivo dos rebanhos, aliado à diminuição pela caça de presas naturais, como porcos-do-mato, veados e tatus, foram apontados como aspectos que favoreciam a predação naquela região.

A perda de animais domésticos por predação precisa ser identificada corretamente, para que medidas apropriadas sejam tomadas, dado que muitas vezes danos são atribuídos errôneamente aos animais silvestres (Cummings, 1971; Bowland et. al., 1992; Oli et al., 1994 e Weber \& Rabinowitz, 1996). Um outro aspecto que também precisa ser determinado é a abrangência do dano, tanto em termos de extensão quanto de severidade (Cummings, 1971).

Bowland e al. (1992) já notavam que a idéia de que todos os predadores são prejudiciais e devem ser mortos aonde quer que sejam encontrados, prevalecia na mente de muitos fazendeiros da África do Sul. Entretanto, esta parece ser uma regra para qualquer país, levando ao extermínio, principalmente, os grandes mamíferos. 
No caso de Parques Nacionais e comunidades vizinhas, Hough (1988) sugere, que o momento para solucionar ou gerenciar conflitos ocorre quando em conseqüência deles passam a existir desvantagens para ambas partes.

Uma das formas de minimizar erros em decisões de manejo de animais silvestres têm sido a elaboração de guias e manuais, tanto para profissionais da área (Roy e Dorrance, 1976), como para proprietários de terras (Bowland et al. 1992). Estes guias fornecem informações sobre a biologia das espécies, identificação do animal causador do dano através de chaves e vestígios, e sugestões de técnicas preventivas e de controle.

Alguns autores acreditam que para que programas de conservação de mamíferos silvestres obtenham resultados positivos a longo prazo é necessário obter o apoio das comunidades locais, assim como solucionar os conflitos envolvendos predação (Reading \& Kellert, 1993; Oli et al. 1994). 


\section{MATERIAL E MÉTODOS}

\subsection{Parque Nacional do Iguaçu}

O Parque Nacional do Iguaçu localiza-se na borda oeste do estado do Paraná ( $25^{\circ} 05^{\prime}-25^{\circ} 41^{\prime} \mathrm{S}$ e $53^{\circ} 38^{\prime} \mathrm{W}$ ), na divisa com Argentina e o Paraguai ( Figura 1).

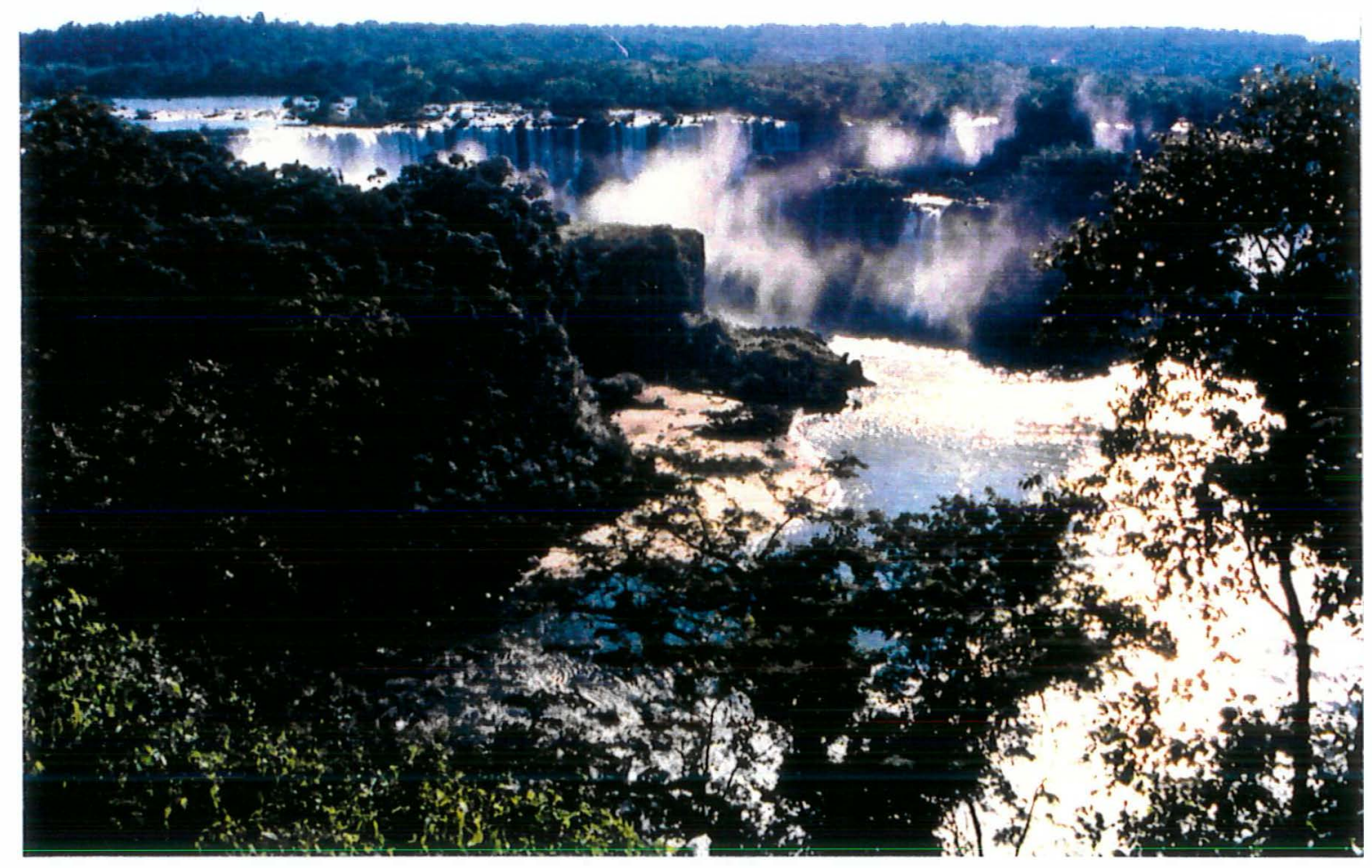

Figura 1 - Vista parcial do Parque Nacional do Iguaçu 
Criado em 1939 para proteger as Cataratas do Iguaçu, o Parque possui atualmente uma área de $185.262,5$ hectares, que juntamente com os 55.000 hectares adjacentes do Parque Nacional Iguazu na Argentina, protege o último trecho significativo de floresta pluvial subtropical do lado oeste da Serra do Mar, no sul do Brasil.

O clima da região é temperado subtropical, com temperaturas médias mensais variando de $25,7^{\circ} \mathrm{C}$ em Fevereiro à $14,6^{\circ} \mathrm{C}$ em julho (Crespo, 1982).

De acordo com a Classificação Fisionômico-Ecológica da Vegetação Neotropical do Projeto RADAMBRASIL, a vegetação do Parque Nacional do Iguaçu está basicamente representada pela floresta estacional semidecidual. Originalmente, a floresta estacional semidecidual estendia-se, no sul do Brasil, por cerca de $81.000 \mathrm{~km}^{2}$. Deste total, permaneceram próximo de $5.000 \mathrm{~km}^{2}$, ou seja $6 \%$ do original, estando os fragmentos em geral, descaracterizados ou profundamente alterados na sua composição e fisionomia ( IBAMA, 1994). Entretanto, a área do Parque Nacional apresenta uma grande diversidade de espécies como a peroba-rosa (Aspidosperma polyneuron), o ipê-roxo (Tabebuia avellanedae) a canela (Ocotea pretiosa), o cedro (Cedrella fissilis) e o palmito (Euterpe edulis). Ocorre ainda, em seu extremo norte, a floresta ombrófila densa contendo trechos de mata de araucária (Araucaria angustifolia).

Apesar de ser uma das unidades de conservação mais antigas do Brasil, poucas pesquisas em fauna foram conduzidas na área. Em um levantamento preliminar de mamíferos, Crawshaw (1995) registrou 42 espécies, incluindo tamanduá-mirim (Tamanduá tetradactyla), veadomateiro (Mazama american), paca (Agouti paca), macaco-prego (Cebus 
apella), irara (Eira barbara), Iontra (Lutra longicaudis), guaxinim Procyon cancrivorus) e 5 espécies de felinos (Panthera onca, Puma concolor, Leopardus pardalis, Leopardus wiedii e Herpailurus yagouaroundi) ( Apêndice 1). Quanto a avifauna destacam-se o gavião-real (Harpia harpya), - macuco (Tinamus solitarius) e o papagaio-de-peito-roxo (Amazona vinacea), todos ameaçados de extinção. Entre os répteis destaca-se o jacaré-de-papo-amarelo (Caiman latirostris), incluído na lista brasileira de espécies ameaçadas de extinção (Pádua e Coimbra-Filho, 1989).

Aliada à diversidade de espécies existentes na área, está o fato do Parque Nacional do Iguaçu ser uma das poucas unidades de conservação do Brasil que possui sua situação fundiária regularizada. Em 1975 cerca de 400 famílias deixaram a área, e em 1986 o último residente foi compensado e também removido. A importância do Parque também foi reconhecida internacionalmente quando em 1986 ele foi incluído na lista de Patrimônio Mundial da Humanidade.

\subsection{Municípios do Entorno}

Cinco municípios têm parte de suas terras englobadas

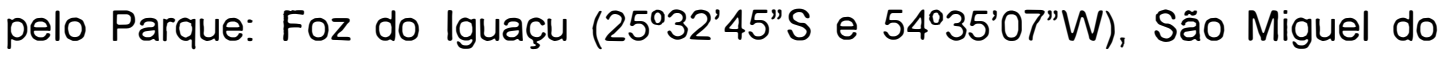

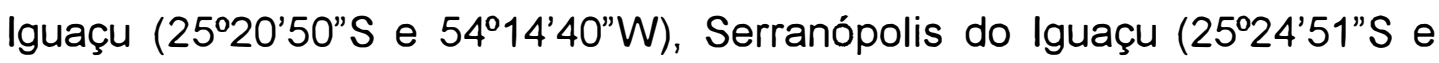

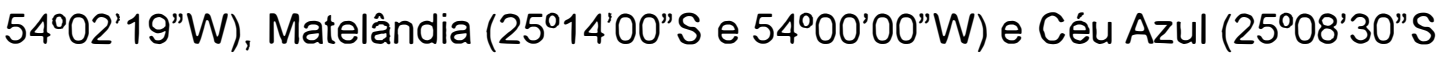
e 5352'00'W). Outros cinco municípios são lindeiros à ele: Santa Terezinha do Itaipu ( $25^{\circ} 25^{\prime} 00^{\prime \prime}$ S e $\left.5^{\circ} 25^{\prime} 00^{\prime \prime} \mathrm{W}\right)$, Santa Tereza do Oeste $\left(2^{\circ} 03^{\prime} 08^{\prime \prime} \mathrm{S}\right.$ e

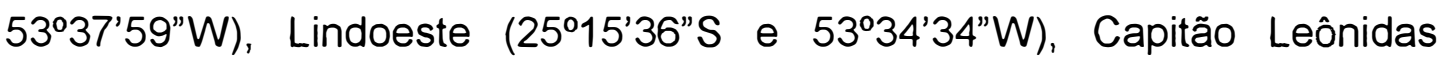

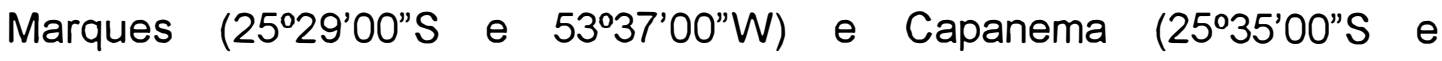
$53^{\circ} 33^{\prime} 00^{\prime \prime}$ ) (Figura 2). 


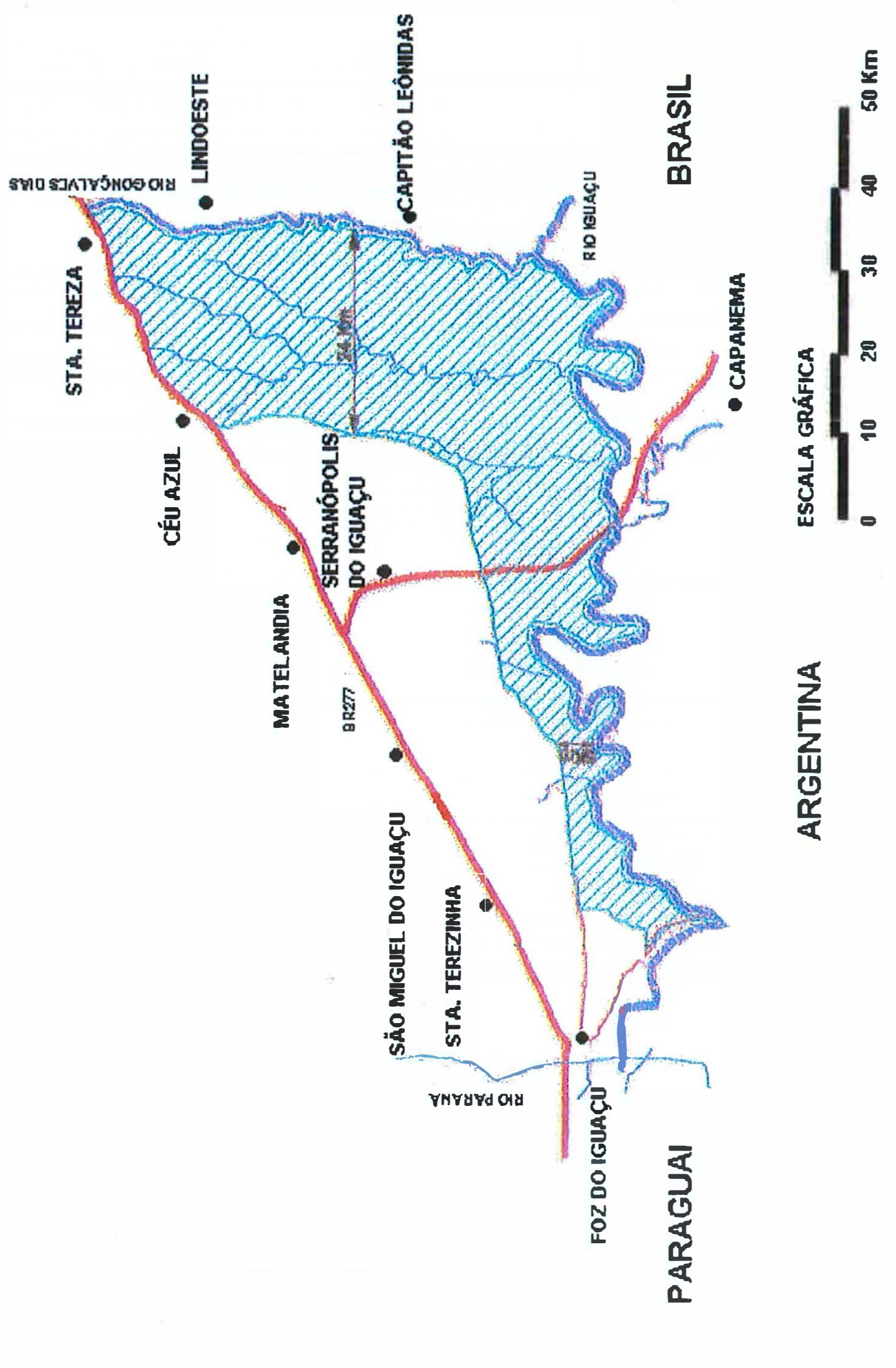


A Tabela 1 apresenta dados referentes ao ano de criação de cada município, tamanho, porcentagem da área abrangida pelo Parque Nacional e número de habitantes. Algumas destas informações foram fornecidas oralmente por funcionários das prefeituras, especialmente secretários de agricultura e meio ambiente, uma vez que não encontravamse registradas.

Tabela 1 - Caracterização dos 10 municípios do entorno do Parque Nacional do Iguaçu ( PNI) quanto a área e o número de habitantes.

\begin{tabular}{|c|c|c|}
\hline $\begin{array}{c}\text { Município } \\
\text { (ano de criação) }\end{array}$ & $\begin{array}{c}\text { Área Total } \mathrm{km}^{2} \\
\text { (\% dentro do PNI) }\end{array}$ & $\begin{array}{c}\text { População } \\
\text { (U=urbana/ } R=\text { rural) }\end{array}$ \\
\hline $\begin{array}{l}\text { Foz do Iguaçu } \\
\text { (1914) }\end{array}$ & $\begin{array}{r}422,000 \\
(3,0 \%)\end{array}$ & $\begin{array}{c}249.658 \\
(U=246.553 / R=3.105)\end{array}$ \\
\hline $\begin{array}{l}\text { São Miguel do Iguaçu } \\
\text { (1961) }\end{array}$ & $\begin{array}{l}894,148 \\
(10,6 \%)\end{array}$ & $\begin{array}{c}24.424 \\
(U=14.648 / R=9.776)\end{array}$ \\
\hline $\begin{array}{l}\text { Serranópolis do Iguaçu } \\
\text { (1995) }\end{array}$ & $\begin{array}{c}477,000 \\
(57 \%)\end{array}$ & $\begin{array}{c}4.402 \\
(U=1.649 / R=2.753)\end{array}$ \\
\hline $\begin{array}{l}\text { Matelândia } \\
\quad(1960)\end{array}$ & $\begin{array}{c}598,468 \\
(52 \%)\end{array}$ & $\begin{array}{c}14.299 \\
(U=9.933 / R=4.366)\end{array}$ \\
\hline $\begin{array}{l}\text { Céu Azul } \\
\text { (1966) }\end{array}$ & $\begin{array}{l}1.153,238 \\
(72 \%)\end{array}$ & $\begin{array}{c}10.443 \\
(U=7.251 / R=3.192)\end{array}$ \\
\hline $\begin{array}{c}\text { Santa Terezinha de Itaipú } \\
\text { (1982) }\end{array}$ & $\begin{array}{l}248,133 \\
(0 \%)\end{array}$ & $\begin{array}{c}17.795 \\
(U=15.645 / R=2.150)\end{array}$ \\
\hline $\begin{array}{c}\text { Santa Tereza do Oeste } \\
\text { (1989) }\end{array}$ & $\begin{array}{c}337,577 \\
(0 \%)\end{array}$ & $\begin{array}{c}12.845 \\
(U=8.155 / R=4.690)\end{array}$ \\
\hline $\begin{array}{l}\text { Lindoeste } \\
\text { (1989) }\end{array}$ & $\begin{array}{c}440,102 \\
(0 \%)\end{array}$ & $\begin{array}{c}7.549 \\
(U=3.398 / R=4.151)\end{array}$ \\
\hline $\begin{array}{l}\text { Capitão Leônidas Marques } \\
\qquad(1964)\end{array}$ & $\begin{array}{l}250,057 \\
(0 \%)\end{array}$ & $\begin{array}{c}17.719 \\
(U=10.636 / R=7.085)\end{array}$ \\
\hline $\begin{array}{l}\text { Capanema } \\
\text { (1951) }\end{array}$ & $\begin{array}{c}415,021 \\
(0 \%)\end{array}$ & $\begin{array}{c}18.012 \\
(U=8.480 / R=9.532)\end{array}$ \\
\hline
\end{tabular}


À exceção de Foz do Iguaçu e Capanema, os municípios vizinhos ao Parque Nacional possuem uma economia baseada na agricultura. Entretanto, somente três deles apresentam taxas de crescimento rural positivo, Santa Tereza do Oeste $(7,76 \%)$, Capitão Leônidas Marques (3,00\%) e Matelândia (1,14\%).

\subsection{Método utilizado para caracterização das propriedades e de danos causados por mamíferos silvestres}

Para caracterizar as propriedades, detectar possíveis interações com animais silvestres e quantificar prejuízos foi elaborado um questionário contendo 24 questões (Apêndice 2). O questionário foi aplicado na forma de entrevistas, amostrando fazendeiros e sitiantes que possuiam terras na divisa com o Parque, nos 10 municípios vizinhos.

Diversos autores têm utilizado questionários como instrumentos de suas pesquisas. Schaefer et al. (1981), por exemplo, incluiram entre seus métodos de coleta de dados sobre perdas de ovelhas por coiotes e cães domésticos, questionários enviados pelo correio para criadores de Montana, Estados Unidos.

Reading \& Kellert (1993) utilizaram entrevistas informais e questionários para examinar os conhecimentos, atitudes e opiniões de fazendeiros com relação a doninha (Mustela nigripes) e o cão-das-pradarias (Cynomys spp). Este trabalho buscou embasar o desenvolvimento de um programa de conservação da doninha através de sua reintrodução no estado de Montana. 
Através de questionários enviados pelo correio, Mcivor \& Conover (1994) avaliaram a percepção de fazendeiros e não-fazendeiros sobre conflitos e tipos de manejo relacionados aos animais silvestres.

Battershill \& Gilg (1996) entrevistaram fazendeiros ingleses para relacionar as práticas de manejo adotadas nas propriedades com comportamentos conservacionistas.

Para medir e comparar conhecimentos, atitudes e interesses de usuários e vizinhos sobre o manejo dos ecossistemas existentes na Base Eglin, pertencente a Força Aérea Americana, no estado da Flórida, Jacobson \& Marynowski (1997) utilizaram, entre outros métodos, questionários e entrevistas. Os resultados obtidos serviram como fundamentação para elaboração e desenvolvimento de novas políticas de manejo para aquela área, enfatizando a necessidade da educação e o envolvimento dos públicos alvo.

Conover (1998) utilizou questionários remetidos pelo correio para avaliar a percepção de produtores agrícolas americanos sobre a vida silvestres.

Jonker et al. (1998) também enviaram questionários, pelo correio, para avaliar a extensão e severidade da predação causada pelo urso-preto (Ursus americanus) em áreas agrícolas, assim como a percepção dos produtores com relação a este problema.

Questionários também foram usados por Naughton-Treves (1998) no estudo dos danos causados por mamíferos silvestres em áreas agrícolas no entorno do Parque Nacional Kibale em Uganda. 
A utilização de questionários possui alguns problemas inerentes (Oli et al.,1994; Naughton-Treves, 1998). Porém, a sua aplicação através de entrevistas, aliada ao cruzamento de certas informações e o conhecimento da área de estudo tornam esta técnica muito útil para o levantamento da percepção de pessoas locais.

A primeira parte do questionário elaborado para os vizinhos do Parque Nacional do Iguaçu buscou traçar um perfil do entrevistado (sexo, idade, grau de instrução, o tipo de relação com a propriedade e tempo de moradia no local). As questões seguintes caracterizaram a propriedade quanto a outros aspectos:

a) tamanho e extensão da divisa com o Parque;

b) presença de remanescentes florestais;

c) presença de mamíferos silvestres

d) tipos de cultivo e tamanho das áreas;

e) criação de animais domésticos;

f) existência de conflitos com animais silvestres, espécies de predadores

e presas envolvidos, quantificação dos prejuízos e diferenciação dos danos por predador;

g) possiveis alternativas de manejo e conservação.

Parte deste questionário foi utilizada para investigar atitudes e conhecimentos relacionados aos animais silvestres. Para analisar as atitudes foi preparada uma escala de 5 pontos do tipo "Likert" (Kubiszyn \& Borich, 1987). Abordagem semelhante foi utilizada por Kellert (1985) para identificar atitudes de norte-americanos com relação aos predadores, principalmente 0 coiote e o lobo.

Uma questão de múltipla escolha abordou o conhecimento do 
entrevistado sobre o comportamento e hábito alimentar de 8 espécies de mamíferos. Para quantificar o conhecimento estabeleceu-se um padrão de notas para cada resposta possível (Apêndice 3). Na contagem final o entrevistado poderia alcançar o mínimo de zero pontos e o máximo de 48 pontos.

A questão onde se registrava a presença de algumas espécies nas áreas amostradas também foi utilizada para investigar a percepção do entrevistado sobre 7 espécies. A escolha das espécies para as questões de conhecimento e atitudes baseou-se em relatos prévios de conflitos com proprietários rurais, não só em áreas vizinhas ao Parque Nacional do Iguaçu mas também em outras áreas naturais protegidas.

A partir da análise dos dados coletados foram discutidas estratégias de manejo e conservação, visando contribuir para minimizar os danos causados tanto por animais silvestres sobre as plantações e criações de animais domésticos, quanto dos sitiantes e fazendeiros sobre animais silvestres. 


\section{RESULTADOS E DISCUSSÃO}

\subsection{Perfil dos Entrevistados}

Entre 1998 e 1999 foram amostradas 60 propriedades, representando aproximadamente $24 \%$ do total de propriedades no entorno do Parque Nacional do Iguaçu. As entrevistas foram conduzidas com 47 homens e 13 mulheres, sendo que $70 \%$ deles estava na faixa compreendida entre 20 e 50 anos.

Cerca de $75 \%$ dos entrevistados eram proprietários das terras, $22 \%$ empregados e $3 \%$ arrendatários. O grau de escolaridade encontrado foi baixo, com $57 \%$ dos entrevistados possuindo apenas o nível primário.

O tempo de residência no local variou entre um mínimo de 8 meses e um máximo de 45 anos. Contrastando com os demais municípios, em Foz do Iguaçu $71 \%$ dos entrevistados não morava na propriedade, apesar do contato quase diário com a mesma.

As entrevistas duraram entre 1 hora e 4 horas (média de $2 \mathrm{~h} 30$ ), dependendo da receptividade dos entrevistados. 


\subsection{Caracterização das Propriedades}

Em 1997 foram feitas diversas tentativas, junto às prefeituras dos municípios do entorno do Parque Nacional do Iguaçu, para se obter informações relacionadas à extensão de suas divisas, ao número de propriedades rurais e suas localizações. Porém, com exceção de Foz do Iguaçu, os dados relacionados às propriedades foram obtidos de maneira informal, através de contatos com secretários de agricultura e meio ambiente, técnicos agrícolas e visitas de campo para identificação e confirmação destas informações. Assim, dados referentes ao número de propriedades adjacentes ao Parque Nacional são aproximados, uma vez que algumas das propriedades já foram inclusive desmembradas ( Tabela 2).

Tabela 2. Número aproximado de propriedades adjacentes ao Parque Nacional do Iguaçu e extensão de divisas por município.

\begin{tabular}{lcc}
\hline \multicolumn{1}{c}{ Município } & $\begin{array}{c}\mathbf{N}^{\circ} \text { de Propriedades } \\
\text { na Divisa com o } \\
\text { Parque Nacional }\end{array}$ & $\begin{array}{c}\text { Extensão da } \\
\text { Divisa } \\
(\mathbf{k m})\end{array}$ \\
\hline Foz do Iguaçu & 15 & 10 \\
São Miguel do Iguaçu & 12 & 15 \\
Serranópolis do Iguaçu & 42 & 15 \\
Matelândia & 14 & 09 \\
Céu Azul & 25 & 30 \\
Santa Terezinha do Itaipu & 20 & 10 \\
Santa Tereza do Oeste & 30 & 12 \\
Lindoeste & 25 & 10 \\
Capitão Leônidas Marques & 15 & 25 \\
Capanema & 49 & 68 \\
\hline
\end{tabular}


O tamanho médio das 60 propriedades amostradas no entorno do Parque Nacional foi de $120 \pm 182$ hectares ( 2 ha -907 ha), sendo que $40 \%$ foi categorizada como pequena propriedade, $28 \%$ como média e $32 \%$ como grande. Nos municípios de Matelândia e Capitão Leônidas Marques nenhum dos locais visitados pertencia a categoria de pequena propriedade (Tabela 3).

Tabela 3 - Número de propriedades amostradas por categoria de tamanho, estabelecida para a região segundo padrões da EMATER (Empresa Paranaense de Assistência Técnica e Extensão Rural).

\begin{tabular}{lccc}
\hline Municipio & $\begin{array}{c}\text { Pequena } \\
\text { (até 25 ha) }\end{array}$ & $\begin{array}{c}\text { Média } \\
(\mathbf{2 5 - 1 0 0 ~ h a ) ~}\end{array}$ & $\begin{array}{c}\text { Grande } \\
\text { (acima 100 ha) }\end{array}$ \\
\hline $\begin{array}{l}\text { Foz do Iguaçu } \\
(\mathrm{n}=7)\end{array}$ & 2 & 1 & 4 \\
$\begin{array}{l}\text { São Miguel } \\
(\mathrm{n}=6)\end{array}$ & 4 & 1 & 1 \\
$\begin{array}{l}\text { Serranópolis } \\
(\mathrm{n}=6)\end{array}$ & 5 & 1 & 0 \\
$\begin{array}{l}\text { Matelândia } \\
(\mathrm{n}=6)\end{array}$ & 0 & 2 & 4 \\
$\begin{array}{l}\text { Céu Azul } \\
(\mathrm{n}=8)\end{array}$ & 2 & 3 & 3 \\
$\begin{array}{l}\text { Santa Terezinha } \\
(\mathrm{n}=6)\end{array}$ & 2 & 2 & 2 \\
$\begin{array}{l}\text { Santa Tereza } \\
(\mathrm{n}=8)\end{array}$ & 5 & 3 & 0 \\
$\begin{array}{l}\text { Lindoeste } \\
(n=5)\end{array}$ & 2 & 2 & 1 \\
$\begin{array}{l}\text { Capitão Leônidas } \\
(\mathrm{n}=5)\end{array}$ & 0 & 1 & 4 \\
$\begin{array}{l}\text { Capanema } \\
(\mathrm{n}\end{array}$ & 2 & 1 & 0 \\
\begin{tabular}{l} 
TOTAL \\
\hline
\end{tabular} & 24 & 17 & 19 \\
\hline
\end{tabular}

As figuras 3 e 4 apresentam vistas parciais de propriedades vizinhas ao Parque Nacional. 


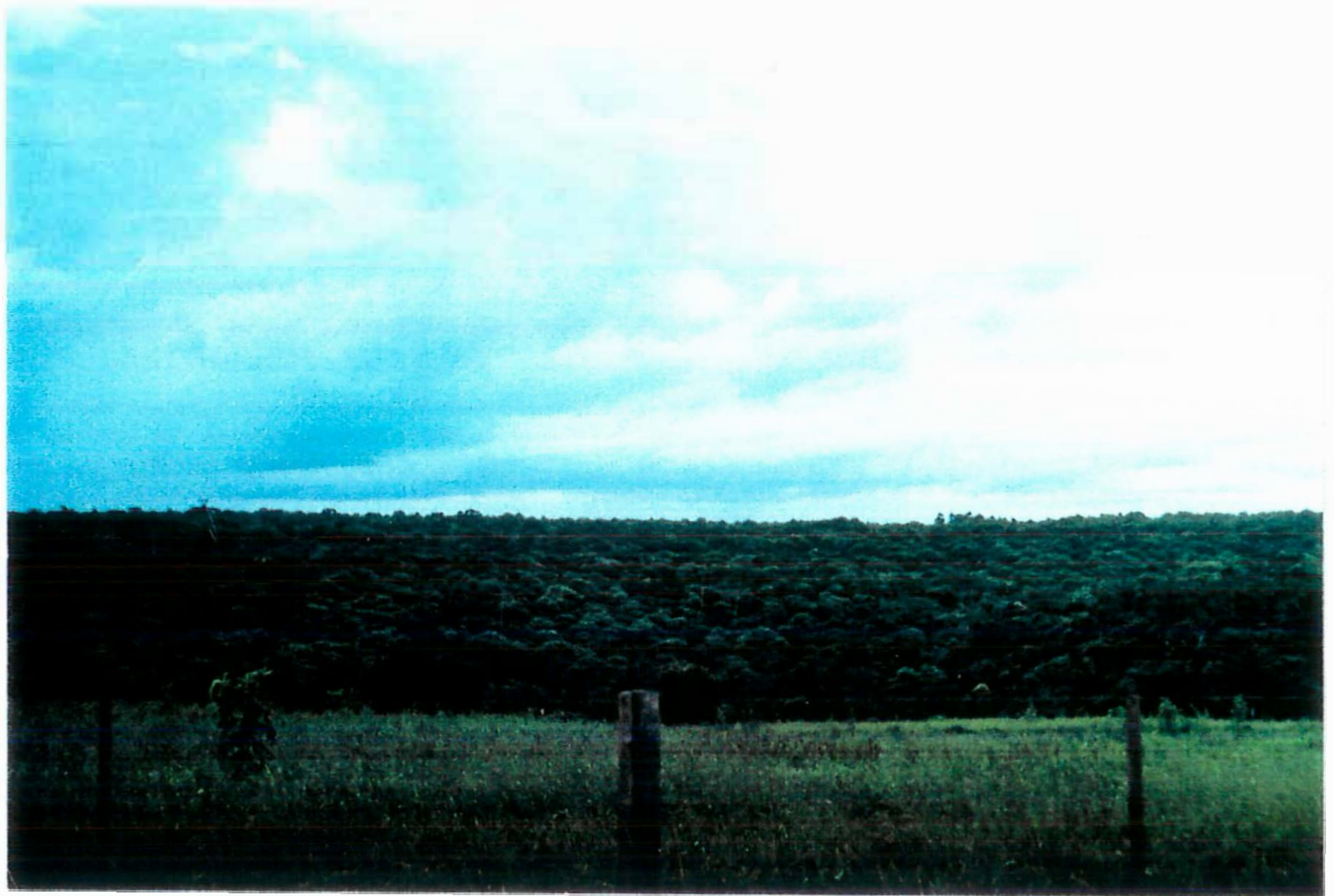

Figura 3 - Vista parcial de propriedade do entorno do Parque Nacional do Iguaçu, município de Foz do Iguaçu.
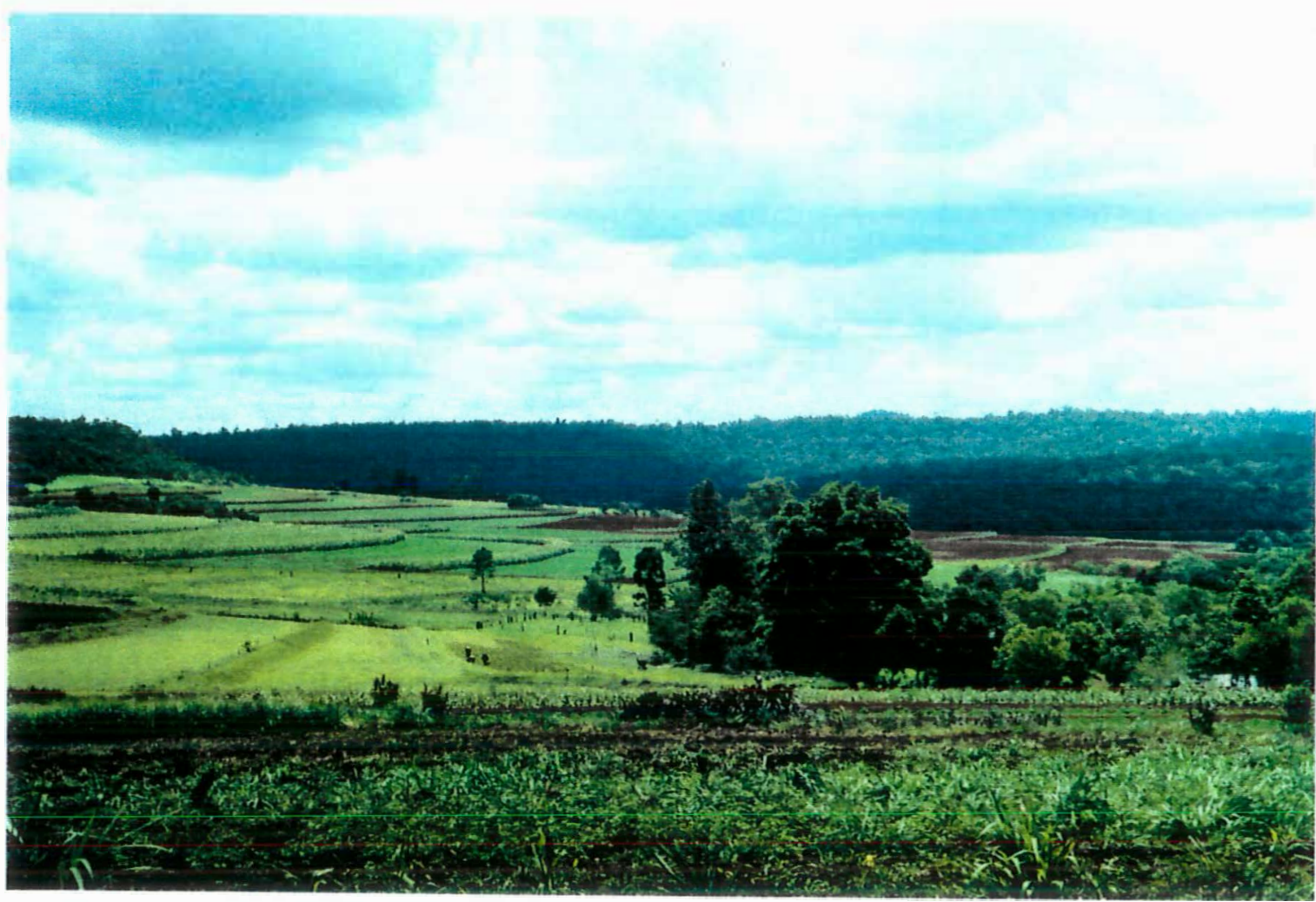

Figura 4 - Vista parcial de propriedade do entorno do Parque Nacional do Iguaçu, municipio de Lindoeste. 
Foz do Iguaçu

Em Foz do Iguaçu as propriedades amostradas ( $n=7)$ variaram de 2,5 à 504 hectares. Somente duas não faziam divisa com o Parque, mas encontravam-se a menos de 1.500 metros do mesmo. A extensão da divisa das cinco restantes variou entre 700 e 3.000 metros, sendo formada pela mata ciliar do rio São João. Estas propriedades possuíam também outras áreas de mata, compreendendo $2,7 \%$ a $33 \%$ de seu tamanho total.

A maior parte da área das propriedades amostradas era ocupada por pastagens, totalizando cerca de 586 hectares. Milho e soja eram plantados de forma alternada em 340 hectares. Somente em uma das áreas amostradas plantava-se também cana-de-açucar (1,2 hectares) como complemento alimentar para o gado.

As criações de animais domésticos eram destinadas tanto para o comércio como para o consumo, exceto cavalos e éguas utilizados para 0 trabalho. A Tabela 4 apresenta uma quantificação aproximada dos animais domésticos existentes nas 7 propriedades e 0 tipo de manejo adotado.

Cinco dos sete proprietários adotavam medidas para proteger as criações de ataques de animais silvestres. Entre as formas mais usuais estavam a utilização de cachorros, cercas com até 10 fios, cerca elétrica, luz, confinamento noturno de galinhas, bezerros e vacas leiteiras, além da retirada de animais domésticos da borda do Parque, após experimentarem perdas. 
Tabela 4. Quantificação de animais domésticos e tipo de manejo adotado em propriedades de Foz do Iguaçu.

\begin{tabular}{ccc}
\hline ANIMAL & QUANTIDADE & TIPO DE MANEJO \\
\hline Gado (corte e leite) & 870 & Semi-extensivo \\
Galinha & 790 & Extensivo ou \\
& & confinamento \\
Pato & 500 & Extensivo \\
Ovelha & 304 & Semi-extensivo \\
Cavalo & 34 & Extensivo de dia e \\
& & confinamento à noite \\
Cabra & 8 & Confinamento \\
\hline
\end{tabular}

\section{São Miguel do Iguaçu}

As propriedades amostradas em São Miguel do Iguaçu $(n=6)$ possuiam entre 9,6 e 192 hectares. Somente uma delas não fazia divisa com o Parque Nacional, estando localizada a cerca de 450 metros de distância. A extensão da divisa entre as cinco propriedades restantes variou de 150 à 1.500 metros, sendo composta principalmente por plantios de soja, milho e pasto.

Quatro das propriedades amostradas possuiam áreas de mata entre $5 \%$ e $12 \%$ de seu tamanho total. Aproximadamente 98 hectares era destinado às pastagens, 69 hectares ao plantio de soja e 46 hectares ao milho. Outras culturas incluíram aveia para o gado (22 hectares), fumo (4,8 hectares) e mandioca, abóbora, melancia e arroz para consumo. 
A Tabela 5 apresenta os tipos e quantidades de animais domésticos criados em São Miguel, assim como o manejo empregado. Cerca de $50 \%$ dos proprietários não julgava necessário proteger as criações da predação de animais silvestres. A outra metade o fazia, principalmente confinando galinhas destinadas à venda e utilizando luz.

Tabela 5. Quantificação de animais domésticos e tipo de manejo adotado em propriedades de São Miguel do Iguaçu.

\begin{tabular}{ccc}
\hline ANIMAL & QUANTIDADE & TIPO DE MANEJO \\
\hline Gado (corte/ leite) & $496(463 / 33)$ & Semi-extensivo \\
Galinha & 406 & Extensivo ou \\
& & confinamento \\
Porco & 17 & Confinamento \\
Cavalo & 05 & Extensivo \\
\hline
\end{tabular}

\section{Serranópolis do Iguaçu}

Serranópolis do Iguaçu foi o municipio com menor variação no tamanho entre propriedades $(n=6)$. A menor tinha uma área de 5 hectares e a maior de 40 hectares. Todas faziam divisa com o Parque em extensões de 600 à 900 metros que abrangiam de mata ciliar à pastos e plantios de soja e milho. A área de mata das propriedades ocupava entre $2 \%$ e $14 \%$ de suas totalidades.

O principal plantio foi o de milho com 39,8 hectares, seguido pela soja com 26 hectares. Cerca de 24 hectares estava ocupado por pastagens. Outros cultivos incluiram aveia para foragem, fumo, 
mandioca, arroz e amendoim.

A Tabela 6 apresenta a relação de animais de criação de Serranópolis do Iguaçu e o tipo de manejo empregado. Quatro proprietários julgavam necessário proteger as criações da predação de animais silvestres. Os principais métodos utilizados foram cerca elétrica, cães, confinamento de novilhos e luz.

Tabela 6. Quantificação de animais domésticos e tipo de manejo adotado em propriedades de Serranópolis do Iguaçu.

\begin{tabular}{ccc}
\hline ANIMAL & QUANTIDADE & TIPO DE MANEJO \\
\hline Galinha & 510 & Extensivo \\
Gado (corte/ leite) & $87(37 / 57)$ & Semi-extensivo \\
Porco & 59 & Confinamento \\
Ovelha & 02 & Extensivo \\
\hline
\end{tabular}

\section{Matelândia}

Em Matelândia o tamanho das propriedades variou de 33,6 à 720 hectares. Todas $(n=6)$ faziam divisa com o Parque Nacional em extensões de 300 à 5.000 metros, contendo principalmente pastagens e plantio de milho e soja. Foram registrados fragmentos de mata nas seis propriedades amostradas, compreendendo entre $3,5 \%$ e $37 \%$ de suas áreas.

Soja e milho foram os principais plantios com 745 hectares, seguido pelas pastagens com 529 hectares, aveia com 125 
hectares e trigo com 96 hectares. Outros plantios incluíram feijão, ervamate, arroz, mandioca e amendoim.

A maior parte das criações de Matelândia foi composta por gado, especialmente de corte (Tabela 7). Cerca de 60\% dos proprietários protegia os animais domésticos do ataque de animais silvestres utilizando luz em chiqueiros e galinheiros, cercas com até 6 fios, especialmente para ovelhas, e retirando o gado quando muito próximo da borda do Parque.

Tabela 7. Quantificação de animais domésticos e tipo de manejo adotado em propriedades de Matelândia.

\begin{tabular}{ccc}
\hline ANIMAL & QUANTIDADE & TIPO DE MANEJO \\
\hline Gado (corte/ leite) & $777(715 / 62)$ & Extensivo \\
Galinha & 255 & Extensivo e Extensivo \\
& & com confinamento \\
& & noturno \\
Ovelha & 106 & Extensivo \\
Cavalo & 28 & Extensivo \\
Porco & 11 & Confinamento \\
\hline
\end{tabular}

Céu Azul

As sete propriedades amostradas em Céu Azul tinham de 24 à 190 hectares. Todas faziam divisa com o Parque Nacional em comprimentos que variavam de 175 à 3.000 metros, contendo plantios de soja, milho, trigo, aveia e pasto. Em seis propriedades existiam entre $1 \%$ e $43 \%$ de áreas de remanescentes de mata, a maioria contínua. 
Cerca de 344 hectares de terra estavam ocupados por pastagens, seguido por milho e soja com 113 hectares e trigo com 93 hectares. Aveia, feijão, mandioca, cana e eucalipto constituíram alguns dos plantios para consumo.

A principal criação em Céu Azul foi a de galinhas para fins comerciais, com aproximadamente 12.419 indivíduos, seguida pelo gado de corte ( Tabela 8). Metade dos proprietários entrevistados protegia suas criações de animais silvestres, utilizando tela e luz nos aviários, confinando novilhos e vacas leiteiras à noite, confinando porcos e mantendo cães.

Tabela 8. Quantificação de animais domésticos e tipo de manejo adotado em propriedades de Céu Azul.

\begin{tabular}{ccc}
\hline ANIMAL & QUANTIDADE & TIPO DE MANEJO \\
\hline Galinha & 12.410 & Extensivo e \\
& & Confinamento \\
Gado ( corte/ leite) & $789(693 / 96)$ & Extensivo \\
Ovelha & 81 & Extensivo \\
Porco & 64 & Confinamento \\
Cavalo & 23 & Extensivo \\
Pato & 10 & Extensivo \\
Galinha-d'angola & 10 & Extensivo \\
\hline
\end{tabular}

Santa Terezinha do Itaipu

Em Santa Terezinha do Itaipu foram amostradas 6 propriedades, com tamanhos variando entre 14,4 à 740,5 hectares. 
Somente uma delas não se encontrava em área adjacente ao Parque Nacional, estando a aproximadamente 400 metros de distância. A extensão das divisas foi de 200 à 1.500 metros, abrangendo principalmente pastagens e plantios de soja. Todas as propriedades possuiam fragmentos de vegetação nativa que compreendiam entre $6 \%$ à $41 \%$ de suas áreas totais.

Os principais cultivos incluíram a aveia, com 464 hectares e soja e milho, plantados alternadamente, com 463 hectares. As áreas de pastagens e trigo corresponderam a 295 e 190 hectares, respectivamente. Em menor escala estavam os plantios de fumo e mandioca.

As galinhas foram a principal criação em Santa Terezinha. Alguns proprietários, inclusive, estavam experimentando criar uma nova raça na região, a Isabrown. Os porcos também apareceram em grande número, sendo utilizados para venda de gordura e carne (Tabela 9). Mais da metade dos proprietários protegia suas criações principalmente pelo uso de cães.

Tabela 9. Quantificação de animais domésticos e tipo de manejo adotado em propriedades de Santa Terezinha do Itaipu.

\begin{tabular}{ccc}
\hline ANIMAL & QUANTIDADE & TIPO DE MANEJO \\
\hline Galinha & 1.845 & Confinamento \\
Porco & 817 & Confinamento \\
Gado (corte/ leite) & $291(238 / 53)$ & Extensivo \\
Ovelha & 53 & Extensivo \\
Cavalo & 10 & Extensivo \\
\hline
\end{tabular}




\section{Santa Tereza do Oeste}

Em Santa Tereza do Oeste as propriedades tinham entre 4,8 e 100 hectares. As oito propriedades envolvidas no estudo faziam divisa com o Parque Nacional através da mata ciliar do rio Gonçalves Dias. Estas extensões variaram entre 56 e 2.000 metros. Seis propriedades tinham também outros fragmentos de mata, totalizando $0,3 \%$ à $14 \%$ de suas áreas.

O principal cultivo foi a pastagem com 117 hectares, seguida pela soja (53 hectares) e milho (39 hectares). Outros plantios, em pequena escala, incluíram a erva-mate, fumo, arroz, parreira, cana-deaçucar e mandioca.

Em Santa Tereza as galinhas foram a principal criação, seguida pelo gado de corte e leite (Tabela 10). Metade dos proprietários protegia seus animais confinando-os à noite ou em períodos em que localizavam pegadas de onça nas proximidades.

Tabela 10. Quantificação de animais domésticos e tipo de manejo adotado em propriedades de Santa Tereza.

\begin{tabular}{ccc}
\hline ANIMAL & QUANTIDADE & TIPO DE MANEJO \\
\hline Galinha & 240 & Extensivo \\
Gado (corte/ leite) & 118 & Extensivo \\
Porco & 66 & Confinamento \\
Cavalo & 07 & Extensivo \\
Ganso & 02 & Extensivo \\
Ovelha & 02 & Semi-extensivo \\
\hline
\end{tabular}




\section{Lindoeste}

Em Lindoeste as propriedades possuiam entre 14,4 e 240 hectares. Todas $(n=5)$ faziam divisa com o Parque Nacional através da mata ciliar do rio Gonçalves Dias, com extensões que variavam de 250 à 4.000 metros. As áreas de mata nas propriedades ocupavam de $2 \%$ à $13 \%$.

Pastagens e milho foram os principais cultivos com 289 e 46 hectares respectivamente. O feijão cobria uma área de 20 hectares, seguido pela erva-mate com 13 hectares. De forma geral, estes dois cultivos, além da mandioca, arroz e batata eram destinados ao consumo. Já - fumo, a vassoura e a amora, mesmo que em pequena escala, foram plantados como possiveis alternativas econômicas.

O gado de corte e leite foram as principais criações em Lindoeste, com cerca de 557 cabeças. Outros animais domésticos, como galinhas e porcos eram utilizados em baixa escala comercial ( Tabela 11).

Tabela 11. Quantificação de animais domésticos e tipo de manejo adotado em propriedades de Lindoeste.

\begin{tabular}{ccc}
\hline ANIMAL & QUANTIDADE & TIPO DE MANEJO \\
\hline Gado (corte/ leite) & $572(505 / 52)$ & Semi-extensivo \\
Galinha & 195 & Extensivo \\
Cavalo & 55 & Semi-extensivo \\
Porco & 28 & Confinamento \\
Ovelha & 18 & Extensivo e \\
& & Confinamento à noite
\end{tabular}


Somente um proprietário não protegia os animais domésticos de possiveis interações com animais silvestres. Todos os outros utilizavam o confinamento noturno, principalmente de filhotes, como uma medida preventiva.

\section{Capitão Leônidas}

O município de Capitão Leônidas Marques apresentou a maior variação no tamanho de propriedades, entre 26 e 907 hectares. As 5 propriedades amostradas faziam divisa com o Parque através do rio Gonçalves Dias, sendo que 4 possuíam mata ciliar. Foram registrados fragmentos de vegetação nativa entre $2,6 \%$ e $17 \%$ da área total das propriedades.

As pastagens foram 0 principal cultivo das áreas amostradas em Capitão Leônidas, ocupando 1.100 hectares, seguida pela soja (146 hectares). Cultivos para consumo próprio incluíram o milho alternado com o feijão ( 24 hectares), a cana-de-açucar, a mandioca e o arroz.

A principal criação em Capitão Leônidas foi o gado de corte, com cerca de 1.600 cabeças, seguida pelo gado leiteiro com 416 cabeças (Tabela 12). Entretanto, praticamente todo o gado de corte pertencia a uma única fazenda.

Três dos proprietários de capitão Leônidas adotavam como medidas para proteger os animais domésticos o confinamento noturno de novilhos e a implantação de pastagens longe da borda do Parque Nacional. 
Tabela 12. Quantificação de animais domésticos e tipo de manejo adotado em propriedades de Capitão Leônidas Marques.

\begin{tabular}{ccc}
\hline ANIMAL & QUANTIDADE & TIPO DE MANEJO \\
\hline Gado ( corte/ leite) & $2.016(1.600 / 416)$ & Semi-extensivo \\
Galinha & 345 & Extensivo \\
Ovelha & 109 & Extensivo e \\
& & Confinamento noturno \\
Porco & 51 & Confinamento \\
Cavalo & 39 & Extensivo \\
\hline
\end{tabular}

\section{Capanema}

Em Capanema as 3 propriedades amostradas tinham entre 4,8 e 26 hectares. Uma delas não fazia divisa com o Parque Nacional, estando a aproximadamente 500 metros de distância. As duas restantes possuiam extensões na divisa de aproximadamente 110 e 300 metros, através do rio Iguaçu. Em ambas a mata ciliar era praticamente inexistente. Fragmentos de vegetação nativa foram registrados para duas propriedades, restando $6 \%$ e $11 \%$ de suas áreas.

A soja foi o principal cultivo com 28,4 hectares de área plantada, seguida pelo milho (5 hectares) e pasto ( 4 hectares). Cultivos para consumo incluíram a mandioca e a cana-de-açucar. Uma das propriedades estava iniciando o cultivo da banana como uma possivel alternativa. A própria secretaria de Agricultura de Capanema mantinha programas de incentivo para plantios de banana, abacaxi e maracujá. Outro dado interessante foi a presença na região de agricultura orgânica de soja para 
exportação.

A principal criação em Capanema foi a de porcos com 226 cabeças, seguida pelas galinhas (Tabela 13). Entretanto, 90\% destes animais pertencia a uma única propriedade que os criava comercialmente. Nenhum dos proprietários protegia suas criações de possiveis interações com animais silvestres.

Tabela 13. Quantificação de animais domésticos e tipo de manejo adotado em propriedades de Capanema.

\begin{tabular}{ccc}
\hline ANIMAL & QUANTIDADE & TIPO DE MANEJO \\
\hline Porco & 226 & Confinamento \\
Galinha & 180 & Extensivo \\
Gado & 16 & Semi-extensivo \\
\hline
\end{tabular}

\subsection{Predação de Mamiferos Silvestres Sobre Animais Domésticos}

Entre 1995 e janeiro de 1999, quarenta e oito proprietários do entorno do Parque Nacional do Iguaçu sofreram predação de mamíferos silvestres sobre suas criações em 66 situações. Em cerca de $62 \%$ dos eventos os predadores envolvidos foram as onças pintada e parda.

As figuras 5 e 6 exemplificam o estado de carcaças de animais abatidos por onças. 


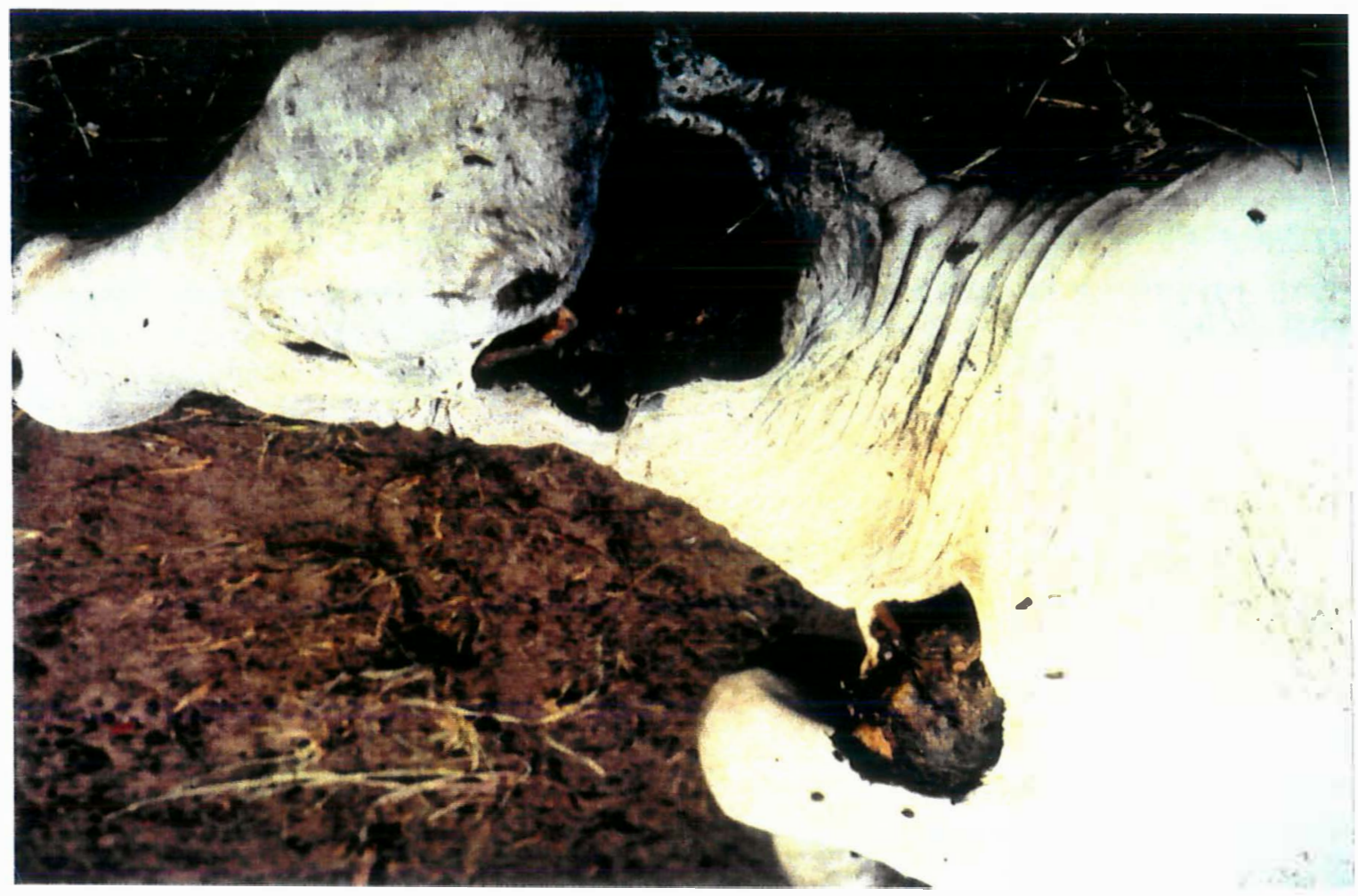

Figura 5 - Estado da carcaça de animal jovem predado por onça

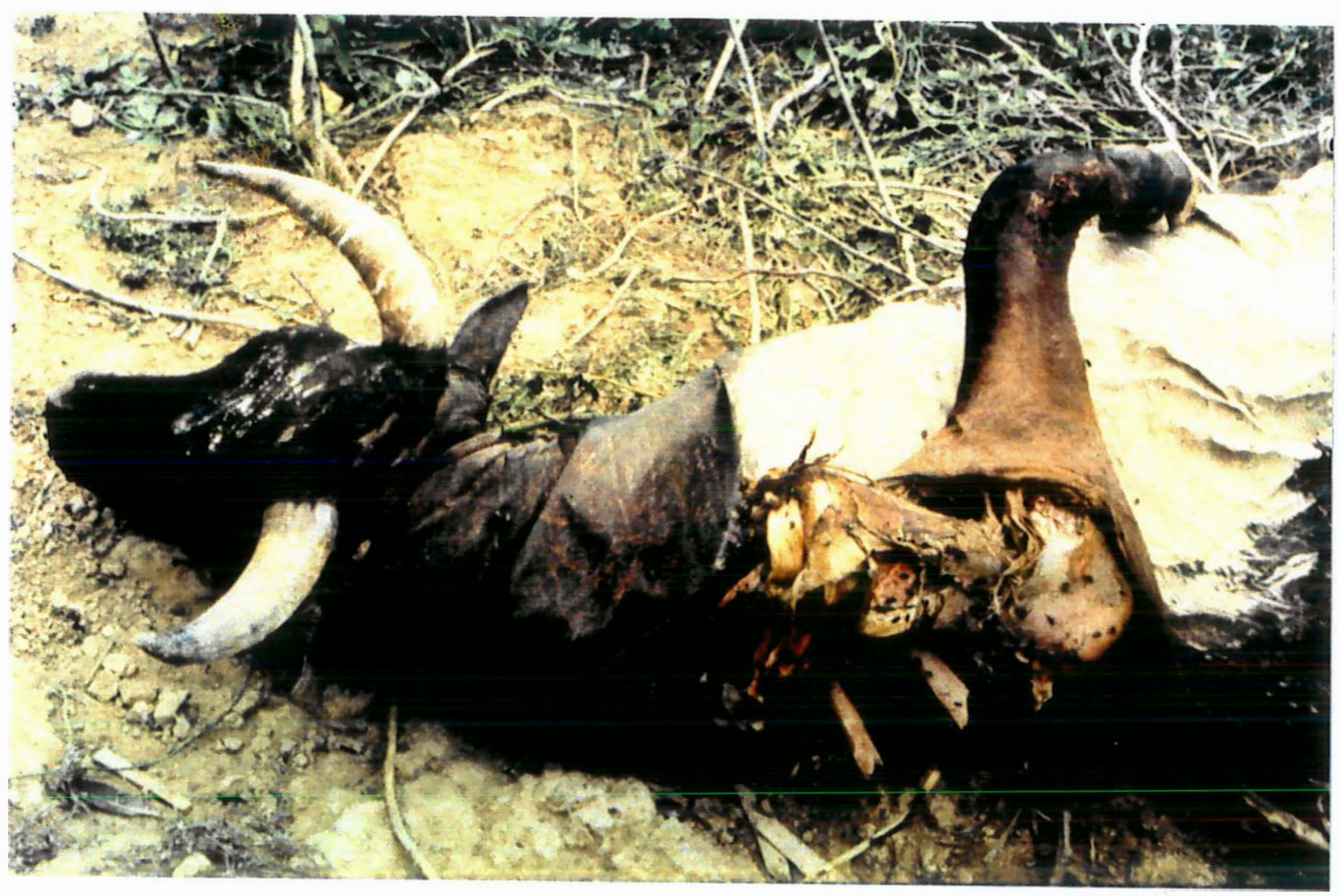

Figura 6 - Estado da carcaça de animal adulto predado por onça 
O número total de animais domésticos predados por mamíferos silvestres foi de 2.298 . Aproximadamente $79 \%$ das perdas foi relacionada às criações de aves, principalmente galinhas-caipira e patos. Para a maior parte dos proprietários, entretanto, o prejuizo com galinhas foi considerado irrisório ( Tabela 14).

Tabela 14. Número de animais domésticos predados por mamíferos silvestres em propriedades vizinhas ao Parque Nacional do Iguaçu, entre 1995 e janeiro de 1999.

\begin{tabular}{cccccccc}
\hline Município & Gado & Ave & Ovelha & Porco & Cão & Cavalo & Total \\
\hline Foz do Iguaçu & 107 & 650 & 48 & - & - & - & 805 \\
São Miguel & 8 & 512 & - & - & 22 & - & 542 \\
Serranópolis & 3 & 225 & - & 2 & 6 & - & 236 \\
Matelândia & 18 & 60 & 16 & - & 3 & - & 97 \\
Céu Azul & 26 & - & 45 & 4 & 18 & 1 & 94 \\
Santa & 16 & 175 & - & - & 4 & - & 195 \\
Terezinha & & & & & & & \\
Santa Tereza & 1 & 70 & 1 & - & - & - & 72 \\
Lindoeste & 1 & 50 & - & - & 7 & - & 58 \\
Capitão & 85 & 20 & 44 & - & - & - & 149 \\
Leônidas & & & & & & & \\
Capanema & - & 50 & - & - & - & - & 50 \\
Total & 265 & 1.812 & 154 & 6 & 60 & 1 & 2.298 \\
\hline
\end{tabular}

O conflito entre proprietários e animais silvestres foi manifestado quando as presas representavam fontes de investimentos e rendimentos. Assim, no caso do gado, por exemplo, os prejuízos alcançaram 
um valor máximo de 17.000 dólares em uma única propriedade no município de Capitão Leônidas Marques. Neste mesmo local, as estimativas de prejuizos com ovelhas obtiveram valores próximos a 2.900 dólares. Vários proprietários dos municípios amostrados haviam, inclusive, parado de criar ovelhas em decorrência dos ataques de onças.

Em alguns locais, a questão da caça predatória dentro do Parque Nacional foi citada, abertamente e por diversas vezes, como um dos principais fatores que estaria contribuindo para os ataques de onças aos animais domésticos. A diminuição de presas naturais, especialmente àquelas encontradas por Crawshaw (1995) como principais itens da dieta de onça-pintada fortalece esta hipótese. Da mesma forma, Weaver et al. (1996) , analisando a resiliência de grandes carnivoros nas Montanhas Rochosas, definiram o termo plasticidade comportamental na aquisição de alimento como a capacidade de indivíduos substituírem um recurso de sua dieta por outro diante de perturbações no meio.

Analisando os resultados de várias pesquisas relacionadas à predação de onça pintada, Weber \& Rabinowitz (1996) enfatizam que quando as onças tinham presas naturais em abundância para se alimentarem, elas representavam pouca ameaça para os humanos e animais domésticos. Exceções ocorreram quando os animais domésticos andavam livremente pelo habitat da onça pintada ou quando esta tornava-se doente ou ferida, frequentemente como um resultado de interações com fazendeiros. Todas as indicações eram de que as onças pintadas poderiam coexistir com humanos, se as criações fossem melhor manejadas e se "animais-problema" fossem retirados sob um rígido controle. 
Todos os entrevistados demonstraram conhecimento que permitia a distinção entre causas naturais de mortalidade e aquelas decorrentes de predação. A própria carcaça do animal abatido foi a principal fonte para identificar os predadores. A maior parte dos proprietários, porém, não consegue distinguir entre a predação de onça-parda e a predação de onça-pintada.

Cerca de $47 \%$ dos proprietários que sofreram danos em criações por mamíferos silvestres não buscou qualquer instituição para resolver o problema, visto que foram ocasionais ou raros. Foz do Iguaçu e Céu Azul foram exceções, sendo que o IBAMA e a Polícia Florestal foram os orgãos mais procurados.

O apêndice 4 apresenta uma lista de predadores e presas, com base nas informações fornecidas pelos proprietários.

\subsection{Predação de Mamíferos Silvestres em Áreas de Plantio}

Dados coletados sobre a predação de mamíferos silvestres em áreas de plantio abrangeram o período entre 1995 à janeiro de 1999. Trinta e um proprietários disseram ter seus cultivos atacados em 48 ocasiões. Cinco espécies de mamíferos silvestres foram responsáveis por $84 \%$ dos eventos: queixada, capivara, lebre-européia, quati e cateto ( Figura $8)$.

A maior parte dos fazendeiros identificava a predação por animal silvestre pelo tipo de dano e por observação direta. Aproximadamente $45 \%$ afirmou que a invasão de animais silvestres em suas áreas de plantio foi ocasional, $39 \%$ que foi raro e $16 \%$ que foi frequente. 


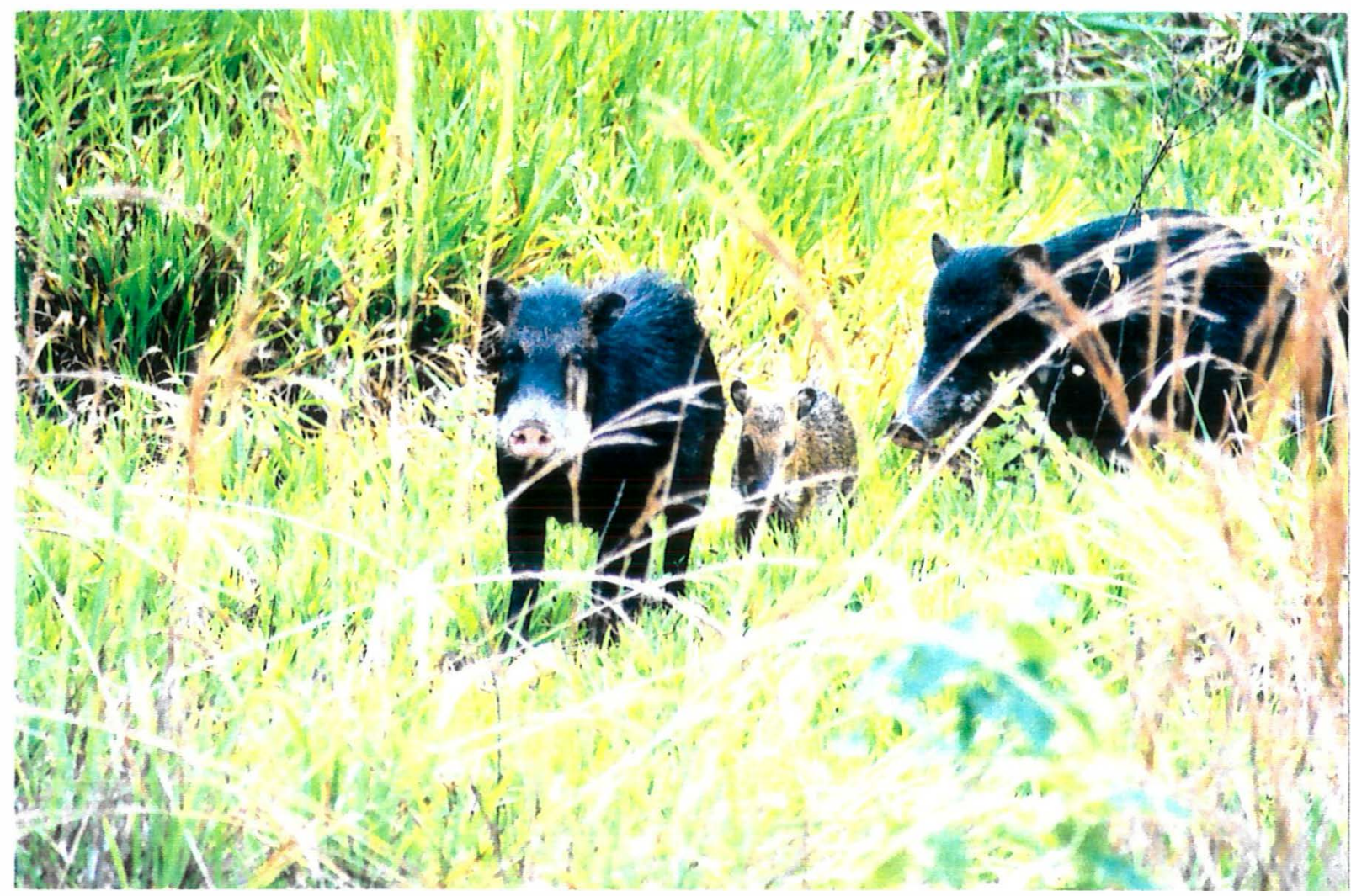

Figura 7 - Queixadas foram os principais predadores das plantações

A Tabela 15 apresenta dados referentes aos plantios que sofreram predação, área atingida, espécie de predador, o prejuízo estimado pelo proprietário e o prejuízo calculado. Este último foi baseado na média de preços do período, através de cotação na cooperativa mais atuante da região, COOPAVEL - Cooperativa Agropecuária de Cascavel.

Alguns autores alertam para uma tendência existente entre fazendeiros em superestimar a quantidade de danos provocados por animais silvestres e os valores dos prejuizos (Oli et al. 1994; NaughtonTreves, 1998). No entorno do Parque Nacional do Iguaçu, houveram diferenças em torno de $34 \%$ entre os prejuízos estimados pelos proprietários e os prejuizos calculados.

Proprietários que não buscaram qualquer instituição para resolver a invasão das áreas de cultivo ( $88 \%$ dos entrevistados), 
Tabela 15 - Caracterização da predação em áreas cultivadas nas propriedades do entorno do Parque Nacional do Iguaçu.

\begin{tabular}{|c|c|c|c|c|}
\hline $\begin{array}{c}\text { Município } \\
\text { ( } \mathrm{n}^{\circ} \text { de } \\
\text { proprietários } \\
\text { que } \\
\text { registraram } \\
\text { predação) } \\
\end{array}$ & Cultivo & $\begin{array}{c}\text { Área } \\
\text { Atingida } \\
\text { ( hectares) }\end{array}$ & Predador & $\begin{array}{l}\text { Prejuízo } \\
\text { Estimado } \\
\quad \text { pelos } \\
\text { Proprietários } \\
\text { (prejuizo } \\
\text { calculado) } \\
\end{array}$ \\
\hline \multirow{2}{*}{$\begin{array}{l}\text { Foz } \\
(5)\end{array}$} & Milho & Irrelevante & Capivara & Irrelevante \\
\hline & Mandioca & 0,2 & Queixada & $\begin{array}{c}\text { Irrelevante } \\
(\mathrm{R} \$ 119,00)\end{array}$ \\
\hline \multirow[t]{2}{*}{$\begin{array}{l}\text { São Miguel } \\
\text { (2) }\end{array}$} & Milho & 4,6 & Queixada & $\begin{array}{c}\mathrm{R} \$ 4.280,00 \\
(\mathrm{R} \$ 2.800,00)\end{array}$ \\
\hline & Mandioca & Irrelevante & Queixada & Irrelevante \\
\hline \multirow[t]{2}{*}{$\begin{array}{c}\text { Serranópolis } \\
(4)\end{array}$} & Milho & 0,3 & Quati & $\begin{array}{c}R \$ 321,00 \\
(R \$ 210,00)\end{array}$ \\
\hline & Milho & Irrelevante & Paca & Irrelevante \\
\hline \multirow[t]{2}{*}{$\begin{array}{l}\text { Matelândia } \\
\text { (5) }\end{array}$} & Milho & 3,5 & Cateto & $\begin{array}{c}\mathrm{R} \$ 3.210,00 \\
(\mathrm{R} \$ 2.100,00)\end{array}$ \\
\hline & Milho & Irrelevante & Queixada & Irrelevante \\
\hline $\begin{array}{l}\text { Céu Azul } \\
\text { (3) }\end{array}$ & Milho & 2,0 & $\begin{array}{l}\text { Queixada; Cateto; } \\
\text { Cachorro-do- } \\
\text { mato; Quati; Tatu }\end{array}$ & $\begin{array}{c}\text { Irrelevante } \\
(\mathrm{R} \$ 1.204,00)\end{array}$ \\
\hline
\end{tabular}




\begin{tabular}{|c|c|c|c|c|}
\hline $\begin{array}{l}\text { Município } \\
\text { ( } n^{\circ} \text { de } \\
\text { proprietários } \\
\text { que } \\
\text { registraram } \\
\text { predação) } \\
\end{array}$ & Cultivo & $\begin{array}{c}\text { Área } \\
\text { Atingida } \\
\text { ( hectares) }\end{array}$ & Predador & $\begin{array}{c}\text { Prejuizo } \\
\text { Estimado } \\
\text { pelos } \\
\text { Proprietários } \\
\text { ( prejuízo } \\
\text { calculado) } \\
\end{array}$ \\
\hline \multirow{2}{*}{$\begin{array}{c}\text { Santa } \\
\text { Terezinha } \\
(3)\end{array}$} & Pastagem & Irrelevante & Veado & Irrelevante \\
\hline & Mandioca & Irrelevante & Tatu & Irrelevante \\
\hline \multirow[t]{2}{*}{$\begin{array}{c}\text { Santa Tereza } \\
\text { (2) }\end{array}$} & Milho & 0,05 & Capivara & $\begin{array}{c}R \$ 53,50 \\
(R \$ 35,00)\end{array}$ \\
\hline & & 0,5 & Quati & $\begin{array}{c}R \$ 460,10 \\
(R \$ 301,00)\end{array}$ \\
\hline \multirow[t]{3}{*}{$\begin{array}{l}\text { Lindoeste } \\
\text { (4) }\end{array}$} & Milho & 1,5 & $\begin{array}{c}\text { Capivara; Paca; } \\
\text { Cateto; } \\
\text { Ratão-do- } \\
\text { banhado; } \\
\text { Macaco-prego; }\end{array}$ & $\begin{array}{l}R \$ 1.380,30 \\
(R \$ 903,00)\end{array}$ \\
\hline & Arroz & Irrelevante & Capivara & Irrelevante \\
\hline & Pastagem & Irrelevante & Capivara & Irrelevante \\
\hline $\begin{array}{c}\text { Capitão } \\
\text { Leônidas } \\
\text { (1) }\end{array}$ & Milho & 1,0 & Capivara & $\begin{array}{c}\text { Irrelevante } \\
(\mathrm{R} \$ 602,00)\end{array}$ \\
\hline $\begin{array}{c}\text { Capanema } \\
\text { (2) }\end{array}$ & Milho & Irrelevante & Capivara & Irrelevante \\
\hline
\end{tabular}

Proprietários que não buscaram qualquer instituição para resolver a invasão das áreas de cultivo ( $88 \%$ dos entrevistados), justificaram suas atitudes baseados na irrelevância dos danos e prejuízos 
ou na ineficiência das instituições governamentais. Cerca de $67 \%$ dos proprietários achava desnecessário controlar a predação de animais silvestres em áreas de plantio.

A solução escolhida como a mais apropriada para resolver problemas de invasão nos cultivos foi cercar o Parque Nacional do Iguaçu, apesar de várias controvérsias quanto a eficiência do método. Foi consenso que o custo desta operação deveria ser do próprio IBAMA, órgão responsável pela vida silvestre do Parque.

O apêndice 5 apresenta uma lista de mamíferos silvestres e suas preferências por cultivos, segundo os proprietários entrevistados.

\subsection{Conhecimentos}

A Tabela 16 apresenta 0 resultado da questão de conhecimento sobre comportamentos e hábitos alimentares de 8 espécies de mamíferos silvestres, por município.

Os proprietários do município de Foz de Iguaçu alcançaram a maior média de conhecimento. Alguns fatores podem colaborar com esta pontuação, tais como a maior proximidade das propriedades com a sede do Parque Nacional, o contato mais freqüente com os policiais florestais, técnicos do IBAMA e pesquisadores em geral, aliado a um nível sócio-econômico também mais alto. Já o município de Capanema apresentou a menor média de conhecimento. Fatores já conhecidos para esta região, como o menor nível sócio-econômico, a pouca integração quanto aos objetivos de conservação e manejo do Parque, aliados às divergências políticas, podem auxiliar a explicar esta pontuação. O pequeno 
número de entrevistados também pode ter contribuído para este resultado.

Tabela 16. Quantificação do conhecimento de proprietários do entorno do Parque Nacional do Iguaçu sobre animais silvestres.

\begin{tabular}{lc}
\hline \multicolumn{1}{c}{ Município } & Média e Desvio Padrão \\
\hline Foz do Iguaçu & $41,6 \pm 2,4$ \\
São Miguel & $40,8 \pm 6,7$ \\
Serranópolis & $39,2 \pm 4,4$ \\
Matelândia & $40,3 \pm 2,1$ \\
Céu Azul & $38,4 \pm 4,6$ \\
Santa Terezinha & $41,3 \pm 4,3$ \\
Santa Tereza & $36,5 \pm 7,1$ \\
Lindoeste & $38,0 \pm 6,4$ \\
Capitão Leônidas & $38,0 \pm 2,1$ \\
Capanema & $30,7 \pm 1,5$ \\
\hline
\end{tabular}

A Tabela 17 apresenta a média geral do conhecimento sobre o comportamento e hábitos alimentares para cada espécie, sendo que a média máxima alcançada poderia ser 6,0 .

De forma geral, a população amostrada parece ter um maior conhecimento sobre as espécies de carnivoros. Isto pode ser explicado pelo próprio contato com problemas relacionados à predação, assim como por um interesse natural que estas espécies despertam sobre as pessoas. Por outro lado, a anta foi a espécie menos conhecida pelos entrevistados, sendo sempre citada pelos moradores mais antigos como pouco comum e habitando áreas mais interiores do Parque. De fato, a falta de contato com este animal, estabelecida por seus hábitos solitários e sua 
raridade, pode justificar este baixo índice.

Tabela 17. Quantificação do conhecimento de proprietários do entorno do Parque Nacional do Iguaçu sobre 8 espécies de mamíferos silvestres.

\begin{tabular}{lc}
\hline \multicolumn{1}{c}{ Espécie } & Média e Desvio Padrão \\
\hline Queixada & $4,3 \pm 0,52$ \\
Cateto & $4,4 \pm 0,5$ \\
Veado & $5,2 \pm 0,7$ \\
Tatu & $4,9 \pm 0,7$ \\
Anta & $3,9 \pm 0,6$ \\
Onça & $5,1 \pm 0,7$ \\
Jaguatirica & $5,4 \pm 0,5$ \\
Cachoro-do-mato & $5,4 \pm 0,7$ \\
\hline
\end{tabular}

Aumentar o conhecimento sobre a vida silvestre das populações que moram no entorno de áreas naturais protegidas pode ser um dos primeiros passos para garantir sua conservação. Entretanto, Kellert et al. (1996) observam que nem sempre o aumento de conhecimento, especialmente sobre predadores, conduz à atitudes positivas. Muitas vezes os esforços precisam ser direcionados aos componentes afetivos envolvidos neste processo.

\subsection{Atitudes}

A Tabela 18 apresenta as atitudes dos proprietários do entorno do Parque Nacional do Iguaçu com relação aos animais silvestres em geral e à algumas espécies de mamíferos, expressas através de uma escala de gosto muito à detesto. 
As atitudes de fazendeiros para com a fauna em geral foram muito positivas. Vários deles expressaram este resultado dizendo que sentiam-se privilegiados por morar tão próximo de uma área protegida. Isto se refletiu também nas atitudes com relação às espécies apresentadas, principalmente o veado.

Nenhuma das espécies despertou atitudes fortemente negativas, exceto as onças que possuem uma tendência nesta direção. Mesmo os outros animais que causam danos nos cultivos e sobre as criações parecem despertar atitudes positivas. Este fato talvez possa ser explicado pelo componente econômico envolvido nestas relações. A maioria dos proprietários considerou os prejuizos causados por mamíferos silvestres como irrelevantes. Existe na comunidade um limite aceitável para danos. Entretanto, àqueles provocados pelas onças possuem um peso maior no orçamento dos proprietários e passam a ser envolvidos por uma mistura de sentimentos que variam entre o medo, a raiva, a competição pelos recursos e a admiração.

Alguns estudos desenvolvidos nos Estados Unidos demonstraram que fazendeiros e criadores de animais domésticos possuiam as atitudes mais negativas com relação aos predadores, especialmente pelo medo de perdas econômicas ( Kellert, 1985; Kellert1986; Reading \& Kellert, 1993). Por outro lado, no Parque Provincial de Algonquin, Canadá, a mortalidade de lobos esteve associada com os movimentos da espécie fora dos limites do Parque. Um dos principais motivos citados por caçadores para matar os lobos era porque simplesmente não gostavam deles (Forbes \& Theberge, 1996). 
Tabela 18. Atitudes de proprietários rurais do entorno do Parque Nacional do Iguaçu com relação à algumas espécies de mamíferos silvestres ( $1^{\text {a }}$ linha: $n^{0}$ de respondentes; $2^{a}$ linha: $\% ; 3^{a}$ linha: $\%$ de pessoas que responderam positivamente ou negativamente, excluindo os indiferentes).

\begin{tabular}{|c|c|c|c|c|}
\hline Gosto Muito & Gosto & Indiferente & Não Gosto & Detesto \\
\hline \multicolumn{5}{|l|}{ Fauna em geral } \\
\hline (25) & (23) & (11) & (1) & (0) \\
\hline 41,7 & 38,3 & 18,3 & 1,7 & 0 \\
\hline \multicolumn{2}{|l|}{80,0} & \multicolumn{3}{|c|}{1,7} \\
\hline \multicolumn{5}{|l|}{ Onças } \\
\hline (9) & (24) & (12) & (11) & (4) \\
\hline 15,0 & 40,0 & 20,0 & 18,3 & 6,7 \\
\hline \multicolumn{2}{|l|}{55,0} & \multicolumn{3}{|c|}{25,0} \\
\hline \multicolumn{5}{|l|}{ Porcos-do-mato } \\
\hline (15) & (23) & (15) & (7) & (0) \\
\hline 25,0 & 38,3 & 25,0 & 11,7 & 0 \\
\hline 63,3 & & \multicolumn{3}{|c|}{11,7} \\
\hline \multicolumn{5}{|l|}{$\begin{array}{l}\text { Jaguatirica } \\
\text { Gatos-do-mato }\end{array}$} \\
\hline 26,7 & 38,3 & 16,7 & 16,7 & 1,7 \\
\hline 65,0 & & \multicolumn{3}{|c|}{18,4} \\
\hline \multicolumn{5}{|l|}{ Veado } \\
\hline (28) & $(26)$ & (4) & $(2)$ & (0) \\
\hline 46,7 & 43,3 & 6,7 & 3,3 & 0 \\
\hline 90,0 & & \multicolumn{3}{|c|}{3,3} \\
\hline
\end{tabular}


Tabela 18 (Continuação). Atitudes de proprietários rurais do entorno do Parque Nacional do Iguaçu com relação à algumas espécies de mamíferos silvestres ( $1^{\mathrm{a}}$ linha: $\mathrm{n}^{0}$ de respondentes; $2^{\mathrm{a}}$ linha: \%; $3^{\mathrm{a}}$ linha: $\%$ de pessoas que responderam positivamente ou negativamente, excluindo os indiferentes).

\begin{tabular}{llllll}
\hline \multicolumn{1}{c}{ Gosto Muito } & Gosto & Indiferente & Não Gosto & Detesto \\
\hline Tatu & & & & \\
$(19)$ & $(23)$ & $(13)$ & $(5)$ & $(0)$ \\
31,7 & 38,3 & 21,7 & 8,3 & 0 \\
\multicolumn{1}{c}{70,0} & & & & 8,3 & \\
Capivara & & & & & \\
$(19)$ & $(24)$ & $(11)$ & $(6)$ & $(0)$ \\
31,7 & 40,0 & 18,3 & 10,0 & $(0)$ \\
& & & & 10,0 & \\
\hline
\end{tabular}

Diversos estudos têm mostrado que a maioria das atitudes das pessoas com relação aos animais é conseqüência da interação de 4 fatores principais. Primeiro, as pessoas possuem certos valores básicos com relação aos animais e a natureza que inevitavelmente afetam suas percepções sobre espécies individualmente. Os autores identificam 9 valores: utilitarista, naturalista, ecológico-científico, estético, simbólico, dominação, humanista, moralista e negativista. Segundo, as atitudes das pessoas são influenciadas pelas características físicas e comportamentais de uma espécie, incluindo tamanho do animal, inteligência, morfologia, modo de locomoção, associações culturais e históricas, entre outros. Terceiro, o conhecimento de uma espécie pode influenciar atitudes. $O$ conhecimento pode variar de um simples entendimento factual à compreensão mais conceitual. Quarto, as percepções são afetadas por 
interações do passado e do presente com espécies particulares, incluindo conflitos, usos econômicos e recreacionais, relações de propriedade e estatus de manejo (Kellert, 1985; Kellert \& Clark, 1991; Kellert, 1992; Kellert et al. 1996; Kellert, 1997)

Pode-se verificar que existe uma parte dos proprietários amostrados no entorno do Parque Nacional do Iguaçu que demonstram indiferença com relação aos animais silvestres. Estas pessoas podem vir a desenvolver tanto atitudes positivas como atitudes negativas, dependendo dos estímulos que receberem.

De acordo com Roth \& Hodgson (1977), as pessoas tendem a generalizar sentimentos positivos e negativos associados com eventos. Assim, um fazendeiro pode responder positivamente sobre sua atitude com relação aos silvestres, mas depois de experimentar algum tipo de dano, sua atitude original provavelmente será alterada (Newhouse, 1990).

No caso específico do Parque Nacional do Iguaçu é preciso que se estabeleça um programa efetivo e descentralizado de educação ambiental, visando não só grupos de turistas e escolares, mas principalmente a comunidade adulta do entorno. Assim, como já constatado em outros estudos (Kellert, 1992; Reading \& Kellert, 1993; Kellert et al. 1996; Oli et al., 1994), o sucesso dos esforços para conservar a vida silvestre no Parque, especialmente dos mamíferos predadores, dependerá não só de variáveis biológicas das espécies, como também de sua aceitação social pelo público. 


\subsection{Manejo e Conservação}

De acordo com Bolen \& Robinson (1995), a seleção natural tem favorecido a maioria dos herbívoros silvestres, os quais possuem características como vigilância, agilidade, velocidade e discrição. Sendo assim, a maioria destes indivíduos escapa à predação. Por outro lado, os animais domésticos, produtos de seleção artificial, são reproduzidos ao longo dos séculos para carne, lã, couro e ovos. Em decorrência, de forma geral, os animais domésticos não conseguem escapar às ações de predadores silvestres, e isto torna quase inevitável o surgimento de conflitos entre os interesses dos criadores e dos predadores.

No entorno do Parque Nacional do Iguaçu, a maior parte dos proprietários não adota medidas específicas para prevenir ou controlar a predação de mamíferos silvestres. Nas áreas de maior incidência tais medidas são mais constantes do que nos locais onde os danos são raros ou ocasionais.

Segundo Dorrance (1983), o manejo de vida silvestre envolve 6 componentes: prevenção, controle, compensação financeira, extensão e educação, pesquisa e avaliação. O objetivo do manejo é, acima de tudo, disponibilizar métodos de prevenção, diminuir o impacto de grandes perdas e criar ou aumentar entre os proprietários uma tolerância aos danos.

Com relação ao primeiro componente são apresentadas a seguir algumas medidas que poderiam ser adotadas no entorno do Parque Nacional do Iguaçu. Algumas delas foram, inclusive, citadas pelos proprietários como possuindo uma eficiência relativa. É provavel que a 
eficiência dos métodos na prevenção de perdas de plantios e de animais domésticos aumente com a utilização de mais de uma estratégia conjuntamente.

\section{Métodos Preventivos}

\section{Aprimorar as Práticas de Manejo da Propriedade}

Este método envolveria um conjunto de ações por parte dos proprietários, entre elas:

a) Evitar deixar animais de criação em áreas de risco, por exemplo bordas de matas;

b) Manter filhotes e fêmeas grávidas, geralmente mais suscetíveis à predação, em potreiros próximos às casas;

c) Recolher à noite, em potreiros próximos às casas, o gado e as ovelhas. Em alguns casos, por representar um esforço muito grande, esta medida poderia estar restrita aos períodos em que a predação torna-se mais provável. Estes períodos incluem a presença de pegadas de onças na propriedade ou arredores ou a constatação de casos em áreas vizinhas;

d) Evitar plantios palatáveis, por exemplo milho, na borda com o Parque Nacional.

\section{Cerca}

As cercas convencionais possuem eficiência relativa $e$ custo elevado. Foi apontada por vários proprietários como sendo um marco para pessoas e não para animais.

3. Cerca eletrificada

A cerca eletrificada emite choques leves quando tocada, impondo restrições ao deslocamento de animais. No Brasil ela é ainda 
pouco utilizada, apesar de possuir um custo inferior ao da cerca convencional e de não requerer mão-de-obra especializada para a sua instalação.

Aguirre e Haim (1997) apontam que entre as aplicações da cerca eletrificada estão a contenção de animais domésticos e a proteção de hortas, pomares e plantações da invasão de animais domésticos e silvestres.

4. Luz

Especialmente para criadores de aves, o uso de luz parece inibir a presença de mamíferos silvestres, principalmente cachorros e gatos-do-mato.

\section{Cães}

Cães pastores podem ser de grande utilidade para auxiliar no manejo do gado e ovelhas, impedindo que os animais se dispersem e entrem, por exemplo em capões de mata ou na área do Parque Nacional.

\section{Métodos de Controle}

Cummings (1971) acredita que a adoção de métodos de controle é uma decisão moral e econômica. Moral porque mistura interesses humanos e o valor da vida silvestre. Econômica porque o custo do controle deve ser menor do que o dano calculado.

Especialmente nos Estados Unidos diversos métodos letais de controle têm sido testados e contestados, principalmente aqueles utilizados para lobos e coiotes (Anderson, 1991; Peek, 1986). Alguns destes 
métodos, são apresentados abaixo:

- Armadilhamento: principalmente através da utilização de gaiolas e trampas, usando isca ou isca de cheiro;

- Caça aos ninhos: os filhotes são mortos, freqüentemente por asfixia, usando-se cartuchos de monóxido de carbono;

- Armas de fogo;

- Envenenamento de carcaças com estriquinina (não seletivo)

- Utilização do composto 1080 (monofluoracetato de sódio), altamente tóxico para canídeos e roedores (seletivo).

Cummings (1971) argumenta que atualmente o objetivo dos programas de controle não é mais o extermínio do animal, mas sim eliminar ou reduzir os danos à níveis toleráveis.

Os Estados Unidos possui uma política nacional para o controle de predadores, cujas principais características são:

- o controle de danos de animais silvestres deve ser designado para garantir a manutenção da vida silvestre nativa e dos habitats;

- os métodos de controle devem reduzir a predação tão seletivamente quanto possível e devem ser direcionados à indivíduos ou populações locais;

- as florestas, pastos e criações de animais domésticos devem ser protegidos dos danos diretos de animais silvestres e de doenças transmitidas por eles, quando os benefícios econômicos e sociais compensarem todos os custos de controle.

Assim, a utilização de métodos não-letais deve ser priorizada, não só no entorno do Parque Nacional do Iguaçu, como em todas as áreas onde danos comprovadamente intoleráveis estejam 
ocorrendo. Nestes casos duas técnicas podem ser utilizadas:

1) Remoção de indivíduos-problema

Bolen \& Robinson (1995) argumentam que em situações onde fazendeiros sofrem altas perdas de ovelhas pela predação de coiotes, a remoção individual dos predadores parece ser mais eficiente do que a adoção de outras medidas. Quigley \& Crawshaw Jr. (1992) também indicam, para casos específicos, a remoção seletiva de onças pintadas como uma alternativa na redução de perdas de gado no Pantanal. Porém, os autores salientam que a relocação de onças-pintada necessita de mais dados e testes.

Dorrance (1983) enfatiza que a remoção do animal/espécie problema deve ser de responsabilidade do governo e do proprietário. Este método deve ser utilizado com base em argumentos sólidos, tais como ocorrer em áreas de alto risco, ser economicamente justificável e sem dano para qualquer população silvestre. De forma geral, este é um método caro, difícil e eficiente somente quando a predação tende a ser localizada.

2) Condicionamento Aversivo

O condicionamento aversivo é um conceito comportamental com um potencial promissor para limitar danos por predadores. O método utiliza a injeção de produtos químicos desagradáveis, como o cloreto de lítio, na carcaça da presa. Em coiotes, o cloreto de lítio provoca enjôos. Após uma experiência negativa o predador evitaria a presa, da mesma forma que evita qualquer situação envolvendo uma experiência sensorial desagradável, como por exemplo, encontros com zorrilhos ( Conepatus sp.) ( Bolen \& Robinson, 1995). 
Conover (1990), por exemplo, testou a injeção de dihidroclorido de emetina em ovos de galinha na diminuição da predação por guaxinim ( Procyon lotor), gambá (Didelphis virginiana) e cangambá (Mephitis mephitis).

\section{Compensação Financeira}

A compensação financeira é um dos componentes de manejo de vida silvestre, segundo Dorrance (1983). Ela é um meio encontrado pelos orgãos responsáveis pela vida silvestre de diversos países de diminuir conflitos entre proprietários de terras, decorrentes de prejuízos econômicos.

Pouco mais da metade dos proprietários amostrados no entorno do Parque Nacional do Iguaçu considera a compensação financeira como uma alternativa de manejo. Entretanto, se assim fosse estabelecida, $70 \%$ acredita que a compensação deveria ser acima de $50 \%$ do valor de perda.

Dorrance (1983) acredita que a compensação financeira é justificável em propriedades particulares porque o bem-estar do animal silvestre depende amplamente do proprietário da terra. Entretanto, o autor ainda argumenta que as compensações devem ser feitas abaixo do valor de mercado para encorajar o uso de técnica preventivas e de controle para minimizar fraudes.

Entre alguns dos critérios sugeridos por Dorrance (1983) para pagamentos de compensção por predação de animais silvestres em 
propriedades particulares, alguns parecem adequados à realidade do entorno do Parque Nacional do Iguaçu:

1) Danos provocados por espécies protegidas por lei (também citado por Cozza et al.,1996);

2) Danos em propriedades produtivas, que constituam fontes significativas de renda para a região;

3) Danos em propriedades onde técnica preventivas e de controle já foram utilizadas, ou não estavam disponíveis;

4) Danos por animais silvestres em situações onde a remoção não é socialmente aceita, por exemplo espécies ameaçadas de extinção.

Dorrance (1983) também argumenta que propriedades ao redor de parques devem ser classificadas em alto ou baixo risco de predação. Áreas de baixo risco seriam as mais elegíveis para compensação. por outro lado, áreas de alto risco devem ter compensação mínima, isto porque os animais silvestres são parte integral do ambiente.

De qualquer forma, a compensação financeira não deve ser a única alternativa para eliminar ou diminuir os conflitos entre proprietários de terras e animais silvestres. Cozza et al. (1996) argumentam que a compensação financeira deve ser utilizada muito mais como um instrumento de conservação ou de moderação de conflitos, do que um fundo disponivel para agricultores.

Ciucci \& Boitani (1998), por exemplo, discutem que na região da Toscana, Itália, os grandes investimentos governamentais na compensação de fazendeiros que sofreram perdas pela predação de lobos, não foram eficientes em reduzir conflitos e a caça ilegal. Os autores enfatizam a necessidade de uma integração de estratégias, que inclue o 
papel crítico das práticas de manejo adotadas nas propriedades e 0 desenvolvimento de programas educativos.

Fuller \& Kittredge (1996) sugerem como alternativa para conservação de grandes carnívoros, que proprietários que possam contribuir financeiramente participem de programas de doações dedutiveis do imposto de renda, para organizações não-governamentais que promovam pesquisa. Estes fundos poderiam, inclusive, ser utilizados para compensar pequenos proprietários em casos de predação comprovada.

Neste contexto, uma outra alternativa, sugerida por vários proprietários, é que os municípios do entorno do Parque Nacional que já recebem "royalties ecológicos" criem também fundos de compensação a partir deste recurso. Os "royalties ecológicos" são provenientes do imposto de circulação de mercadorias (ICMS), cujo destino principal é sua aplicação em projetos conservacionistas. Este incentivo de alguns governos estaduais, beneficia os municípios que possuem em seus territórios unidades de conservação e que se sejam diretamente influenciados por elas. Atinge também municípios com mananciais de abastecimento público. No estado do Paraná os "royalties ecológicos" foram instituidos desde janeiro de 1992. Dos municípios do entorno do Parque Nacional do Iguaçu, 8 recebem "royalties", que variam entre $0,13 \%$ à $9,9 \%$ : Foz do Iguaçu, Santa Terezinha do Itaipu, São Miguel do Iguaçu, Serranópolis do Iguaçu, Matelândia, Céu Azul, Santa Tereza do Oeste e Capanema.

Outra estratégia de manejo que poderia ser adotada para - Parque Nacional do Iguaçu é o estabelecimento efetivo de sua zona tampão. Noss et al. (1996) discutem a adoção de zonas tampão (também denominadas como zonas de manejo do ecossistema, áreas de manejo 
adaptado, zonas de uso manejado ou zonas de cooperação), como alternativas possiveis na proteção de espécies e propriedades.

No Brasil, o Sistema Nacional de Unidades de Conservação estabelece que o entorno de uma unidade de conservação está sujeito a normas e restrições para o desenvolvimento de atividades, de forma a minimizar os impactos sobre a unidade. O limite legal destas áreas circundantes abrange um raio de $10 \mathrm{~km}$, cuja definição de atividades é de responsabilidade do orgão governamental responsável pela unidade e dos orgãos licenciadores (Orlando, 1997). 


\section{CONCLUSÕES}

O conflito homem-animal silvestre é provavelmente um dos principais problemas de conservação no Brasil, principalmente nas regiões adjacentes aos parques nacionais e outras áreas naturais protegidas. A alteração dos ambientes do entorno e, em alguns casos, a caça indiscriminada de espécies de topo de cadeia e suas presas podem levar a um desequilíbrio do ecossistema, ocasionando, entre outros problemas, a invasão de plantios e a predação de animais domésticos.

A obtenção de dados sobre as áreas potenciais de ocorrência de predação por mamíferos silvestres, a extensão dos danos causados e a relação custo-benefício do manejo são essenciais para a elaboração de estratégias de conservação das espécies envolvidas, não só no Parque Nacional do Iguaçu, como em outras localidades.

A amostragem realizada entre os proprietários de terras do entorno do Parque Nacional do Iguaçu, indica que os mesmos são tolerantes quanto às invasões de animais silvestres em áreas de cultivo. Grande parte deles considera, inclusive, os danos e prejuízos como irrelevantes.

Por outro lado, a predação sobre as criações de animais domésticos por onças parda e pintada envolve perdas econômicas altas e pode conduzir ao desenvolvimento de atitudes negativas para com estes 
animais. Porém, isto não é manifestado com relação ao cachorro-do-mato, jaguatirica e outros felinos menores. Apesar de seus ataques às criações de aves, especialmente galinhas, serem freqüentes, os prejuízos são considerados irrelevantes.

De forma geral, os proprietários do entorno do Parque Nacional do Iguaçu possuem dois componentes importantes que facilitam o seu apoio e envolvimento na conservação de mamíferos silvestres: conhecimento básico sobre as espécies e atitudes positivas. Desta forma, eles devem ser encorajados a prevenir conflitos com animais silvestres, através de programas de extensão que disponibilizem informações técnicas. Existe também a necessidade do desenvolvimento de um programa de educação conservacionista específico para este público, que envolva tanto componentes cognitivos como afetivos. 


\section{REFERÊNCIAS BIBLIOGRÁFICAS}

AGUIRRRE, J. e HAIM, S. L. Cerca eletrificada. $2^{\mathbf{a}}$ impressão. Campinas: Coordenadoria de Assistência Técnica Integral. Instrução Prática 250. 1997. $24 \mathrm{p}$.

ANDERSON, S. H. Animal damage. In: Anderson, S. H. Managing our wildlife resources. 2.ed. Prentice Hall, 1991. cap. 22, p.430-446.

BATTERSHILL, M. R. J.; GILG, A. W. New approaches to creative conservation on farms in South-west England. Journal of Environmental Management, vol. 48, p. 321-340, 1996.

BOLEN, E. G.; ROBINSON, W. L. Wildlife ecology and management. 3 ed. New Jersey: Prentice Hall, 1995. 620 p.

BOMAN, M. Estimating costs and genetic benefits of various sizes of predators population: The case of bear, wolf, wolverine and lynx in Sweden. Journal of Environmental Management, vol. 43, p. 349-357, 1995.

BOWLAND, A. E.; MILLS, M.G.L.; LAWSON, D. Predators and farmers. Johannesburg: The Penrose Press, 1992. $55 \mathrm{p}$. 
BRAYSER, M. Managing vertebrate pests: Principles and strategies. Canberra: Bureau of Resources Sciences, 1993. 58p.

CONOVER, M. R. Reducing mammalian predation on eggs by using a conditioned taste aversion to deceive predators. Journal of Wildlife Management, v. 54, n. 2, p. 360-365, 1990.

CONOVER, M. R. Perceptions of American agricultural producers about wildlife on their farms and ranches. Wildlife Society Bulletin, v. 26, n. 3, p.597-604, 1998.

CONOVER, M.R.; DECKER, D.J. Wildlife damage to crops: Perceptions of agricultural and wildlife professionals in 1957 and 1967. Wildlife Society Bulletin, v.19, p.46-52,1991.

CHOQUENOT, D.; MCLLROY, J.; KORN, T. Managing vertebrate pests: Feral pigs. Canberra: Bureau of Resources Sciences, 1993. 45p.

CIUCCI, P.; BOITANI, L. Wolf and dog depredation on livestock in central Italy. Wildlife Society Bulletin, v. 26, n. 3, p. 504-514, 1998.

COZZA, K.; FICO, R.; BATTISTINI, M.L. The damage-conservation interface illustrated by predation on domestic livestock in Central Italy. Biological Conservation, vol. 78, p. 329-336, 1996.

CRAWSHAW, P.G., JR. Comparative ecology of ocelot ( Felis pardalis ) and Jaguar ( Panthera onca ) in a protected subtropical forest in Brazil and Argentina. Gainesville, 1995. 190p. Thesis (Ph.D.) - University of Florida. 
CRESPO, J.A. Ecologia de la comunidade de mamíferos del Parque Nacional Iguazú, Missiones. Rev. Mus. Argentino Cienciais Naturales "Bernadino Rivadavia". Ecologia, v.3, p.45-162, 1982.

CUMMINGS, M. W. Wildlife damage problems. In: TEAGUE, R. D. ( Ed.)

A manual of wildlife conservation. Washington, DC : The Wildlife Society, 1971. p. 85-89.

DORRANCE, M.J. A. Philosophy of problem wildlife management. Wildlife Society Bulletin, v.11, n.4, p.319-324, 1983.

DOTTO, J. C. P. Estudo da dieta de Pseudolopex gymnocercus ( Fisher, 1814) e de Cerdocyon thous ( Linnaeus, 1766) (Mammalia, Canidae) e sua relação com a mortalidade de carneiros no Rio Grande do Sul. Porto Alegre, 1997. 80p. Dissertação (M.S) - Pontifícia Universidade Católica do Rio Grande do Sul

FORBES, G. J.; THEBERGE, J. B. Cross-boundary management of Algonquin Park wolves. Conservation Biology, v. 10, n. 4, p. 1091-197, 1996.

FULLER, T. K.; KITTREDGE JR., D.B. Conservation of large forest carnivores. In: DEGRAAF, R. M. \& MILLER, R. I. ( Eds) Conservation of faunal diversity in forest landscape. 1996. Chapman \& Hall, 137-163.

HANLEY, N.; SUMNER, C. Bargaining over common property resources: Applying the coase theorem to red deer in the Scottish highlands. Journal of Environmental Management, n. 43, 87-95. 1995 
HENZEL, R. Benefits and costs of vertebrate pest control and value. $9^{\text {th }}$ Australian Vertebrate Pest Control Conference, Adelaide, Australia. P. 303-306, 1991

HOUGH, J.L. Obstacles to effective management of conflicts between National Parks and surrounding human communities in developing coutries. Environmental Conservation, v.15, n.2, p.129-136, 1988.

HOWARD, W.E. Predator control: Whose responsability?. BioScience, v.24, n.6, p.359-363, 1974.

INSTITUTO BRASILEIRO DE MEIO AMBIENTE E DOS RECURSOS NATURAIS RENOVÁVEIS. Parque Nacional do Iguaçu - Plano de ação emergencial. Brasília: 1994. 123 p.

INSTITUTO BRASILEIRO DO DESENVOLVIMENTO FLORESTAL. Plano de Manejo do Parque Nacional de Iguaçu. Brasília: 1981. 104p.

JACOB, A . A . Ataques de predadores à criação rural no entorno do Parque Nacional da Serra da Capivara. CENAP/ IBAMA, 1997. 5 p. ( Relatório Técnico)

JACOBSON, S. K. and MARYNOWSKI, S. B. Public attitudes and knowledge about ecosystem management on Department of Defense Land in Florida. Conservation Biology, v.11, n. 3, p. 70-781, 1997.

JANZEN, D. H. The eternal external threat. In: SOULÉ, M. E. (ed). Conservation biology: The science of scarcity and diversity.1986. Sinauer Associates, Inc. Publishers, 286-303. 
JONKER, S. A.; PARKHURST, J. A.; FIELD, R.; FULLER, T. K. Black bear depredations on agricultural commodities in Massachusetts. Wildlife Society Bulletin, v. 26, n. 2, p. 318-324, 1998.

JOHNSON, S. J.; GRIFFEL, D. E. Sheep losses on grizzly bear range. Journal of Wildlife Management, v. 46, n. 3, p. 786-791, 1982.

KELLERT, S. R. Public perceptions of predators, particularly the wolf and coyote. Biological Conservation, n.31, p.167-189. 1985

KELLERT, S.R. The Public and the timber wolf in Minnesota. Transactions of the North American Wildlife \& Natural Resources Conference v.51, p.193-200, 1986.

KELLERT, S.R. Public attitudes toward bears and their conservation. In: CLEAR, J.J.; SERVHEEN, C.; LYON, L.J. Proceeding Of The Ninth International Conference On Bear Research And Management. Grenoble: 1992. p.293-305.

KELLERT, S.R. The value of life: Biological diversity and human society. Washington, D.C.: Island Press, 1997. p.263.

KELLERT, S.R.; CLARK, T.W. The theory and of a wildlife policy framework. In: MANGUN W.R. Public Policy Issues in Wildlife management. New York: Greenwood Press, 1991. P.17-36.

KELLERT, S.R.; BLACK, M.; RUSH, C.R.; BATH, A.J. Human culture and large carnivore conservation in North America. Conservation Biology, v.10, n.4, p.977-990, 1996. 
KUBISZYN, T.; BORICH, G. Educational testing and measurement Classroom application and pratice. 2.ed. Glenview: Scott, Foresman and Company, 1987. p.467.

MAHLER JR., J.K.F.; OLIVEIRA, L.F.B. Problemas causados por mamíferos silvestres (Carnivora, Artiodactyla e Perissodactyla) em propriedades vizinhas ao Parque Estadual do Turvo, RGS. Resumos do XXI Congresso Brasileiro de Zoologia, Porto Alegre, Rio Grande do Sul. p.259, 1996.

MARGARIDO, T.C.C. Mamíferos ameaçados de extinção no Paraná. In: SECRETARIA DE ESTADO DO MEIO AMBIENTE. Lista vermelha de animais ameaçados de extinção no Estado do Paraná. Curitiba: SEMA/GTZ, 1995. p.5-45.

MCIVOR, D. E. and CONOVER, M. R. Perceptions of farmers and non-farmers toward management of problem wildlife. Wildlife Society Bulletin, v. 22, n. 2, p. 212-219, 1994.

NAUGHTON-TREVES, L. Predicting patterns of crop damage by wildlife around Kibale National Park, Uganda. Conservation Biology, v.12, n.1, p.156-168, 1998.

NEWHOUSE, N. Implications of attitude and behavior research for environmental conservation. Journal of Environmental Education, v. 22, n. 1, p. 26-32. 1990.

NOSS, R. F.; Quigley, H. B.; HORNOCKER, M. G.; MERRIL, T.; PAQUET, P. C. Conservation biology and carnivore conservation in the Rocky Moutains. Conservation Biology, v.10, n.4, p. 949-963, 1996. 
OLI, M.K.; TAYLOR, I.R.; ROGERS, M.E. Snow leopard Panthera uncia predation of livestock: an assessment of local perceptions in Annapurna Conservation Area, Nepal. Biological Conservation, v.68, p.63-68, 1994.

ORLANDO, $\mathrm{H}$. Unidade de conservação e manejo da zona de entorno. In: CONGRESSO BRASILEIRO DE UNIDADES DE CONSERVAÇÃO, 1.; Curitiba, 1997. Anais. vol. 2, p. 764-775.

PÁDUA, M.T.J.; COIMBRA-FILHO, A.F. Os Parques Nacionais do Brasil. José Olympio Editora, 1989. 223p.

PEEK, J. M. A review of wildlife management. Prentice Hall, 1986. cap. 10, p. 224-278: Predation.

QUIGLEY, H. B.; CRAWSAHAW JR., P. G. A conservation plan for the jaguar Panthera onca in the Pantanal region of Brazil. Biological Conservation, v. 61, p. $149-157$

READING, R.P.; KELLERT, S.R. Attitudes toward a proposed reintroduction of black-footed-ferrets ( Mustela nigripes ). Biological Conservation, v.7, n.3, p.569-580, 1993.

ROBEL, R. J.; DAYTON, A. D.; HENDERSON, F. R.; MEDUNA, R. L. and SPAETH, C. W. Relationships between husbandry methods and sheep losses to canine predators. Journal of Wildlife Management, v.45, n.4, 894-911. 1981.

ROTH, C. Z. ; HODGSON, R. W. The contribution of percepcion training to interpretation effectiveness: na experiment. The Journal of Environmental 
Education, vol. 9, n. 1, p. 23-30. 1977

ROY, L.D.; DORRANCE, M.J. Methods of investigating predation of domestic livestock: A manual for investigations officers. Edmonton: Alberta Agriculture, 1976. 54p.

SCHAEFER, J. M.; ANDREWS, R. D.; DINSMORE, J. J. An assessment of coyote and dog predation on sheep in southern lowa. Journal of Wildlife Management, v. 45, n. 4, p. 883-893, 1981.

SCHALLER, G.B. Carnivores and conservation biology. In: GITTLEMAN, J.L.. Carnivore behavior and evolution. Cornell University Press, 1996. v.2, p.1-10.

SAETHER, B.E.; JONSSON,B. Conservation biology faces reality. Trends in Ecology and Evolution, v.6, n.2, p.37-38, 1991.

TILL, J. A.; KNOWLTON, F. F. Efficacy of denning in alleviating coyote depredation upon domestic sheep. Journal of Wildlife Management, v. 47, n. 4 , p.1018-1025, 1983.

WEAVER, J.L.; PAQUET, P.C.; RUGGIERO, L.F. Resilience and conservation of large carnivores in the Rocky Mountains. Conservation Biology, v.10, n.4, p.964-976, 1996.

WEBER, W.; RABINOWITZ, A. A global perspective on large carnivore conservation. Conservation Biology, v.10, n.4, p.1046-1054, 1996. 
YOM-TOV, Y.; ASHKENAZI, S. and VINER, O. Cattle predation by the golden jackal ( Canis aureus) in the Golan Heights, Israel. Biological Conservation, v.73, p.19-22. 1995. 
Apêndice 1. Espécies de mamíferos registradas no Parque Nacional do Iguaçu, ou em áreas imediatamente próximas (atualizada a partir de Crawshaw, 1995 ). Os destaques são para as espécies ameaçadas de extinção, a partir de critérios da União Internacional para Conservação da Natureza, segundo Margarido, 1995.

MARSUPIALIA

Gambá-de-orelha-preta ( Didelphis aurita)

Gambá-de-orelha-branca ( $D$. albiventris)

Cuíca-de-quatro-olhos ( Philander opossum)

Cuíca lanosa( Caluromys lanatus)

\section{EDENTATA}

Tatu-galinha ( Dasypus novemcinctus)

Tatu-peludo( Euphractus sexcintus)

Tamanduá-mirim(Tamandua tetradactyla)

PRIMATAS

Macaco-prego ( Cebus apella)

Bugio ( Alouatta fusca) ( *

CARNIVORA

Cachorro-do-mato ( Cerdocyon thous)

Guaxinim (Procyon cancrivorus)

Cachorro-do-mato-vinagre ( Speothos venaticus) $\left({ }^{\star \star}\right)$

Quati ( Nasua nasua)

Furão ( Galictis cuja)

Irara ( Eira barbara)

Lontra ( Lutra longicaudis) ( * )

Ariranha ( Pteronura brasiliensis) $\left(^{\star \star *}\right)$

Jaguatirica ( Leopardus pardalis) $\left({ }^{*}\right.$ )

Gato-maracajá( L. wiedii) $\left({ }^{*}\right)$

Onça-parda ( Puma concolor) (*)

Jaguarundi ( Herpailurus yaguarondi)

Onça-pintada ( Panthera onca) $\left({ }^{*}\right.$ *)

* Vulnerável ${ }^{\star \star}$ Em perigo ${ }^{\star \star \star}$ Extinta ( ou praticamente extinta) 
Apêndice 1 Cont. Espécies de mamíferos registradas no Parque Nacional do Iguaçu, ou em áreas imediatamente próximas ( atualizada a partir de Crawshaw, 1995 ). Os destaques são para as espécies ameaçadas de extinção, a partir de critérios da União Internacional para Conservação da Natureza, segundo Margarido, 1995.

\section{PERISSODACTYLA}

Anta ( Tapirus terrestris) $\left({ }^{\star *}\right)$

\section{ARTIODACTYLA}

Veado-mateiro ( Mazama americana)

Veado ( M. nana)

Cateto ( Tayassu tajacu)

Queixada ( T. pecari) (*)

\section{RODENTIA}

Akodon montesis

A. nigrita

A. cf. cursor

A. cf. serrensis

A. cf. azarae

Oryzomys flavescens

$O$. nigripes

Rato-d'água ( Nectomys squamipes)

Holochilus brasiliensis

Esquilo ( Sciurus aestuans)

Preá ( Cavia sp.)

Ouriço ( Sphygurus prehensilis)

Cutia ( Dasyprocta azarae)

Paca ( Agouti paca) (*)

Capivara ( Hydrochoerus hydrochaeris)

LAGOMORPHA

Tapiti ( Silvilagus brasiliensis) (*)

* Vulnerável ${ }^{\star \star}$ Em perigo ${ }^{\star \star \star}$ Extinta ( ou praticamente extinta) 
Apêndice 2 - Questionário utilizado nas entrevistas com proprietários do entorno do Parque Nacional do Iguaçu.

Data:

Nome da Propriedade:

Municipio:

Localização:

1. Nome

2. Idade:

3. Sexo: ( ) M ( ) F

4. Grau de Instrução:

( ) Analfabeto

( ) Primário Incompleto

( ) Primário Completo

( ) Ginasial Incompleto

( ) Ginasial Completo

( ) Colegial Incompleto

( ) Colegial Completo

( ) Técnico. Qual?

( ) Superior. Qual?

5. Tipo de relação com a propriedade:

( ) Proprietário

( ) Meieiro

( ) Empregado Qual ocupação?

( ) Outra. Qual?

6. Há quanto tempo vive no local?

7. Qual o tamanho da propriedade?

8. A área faz divisa com o Parque Nacional?

( ) $\operatorname{Sim}$ ( ) Não

8.1 Para reposta afirmativa: Qual o tamanho da divisa?

8.2 O que existe na divisa:

( ) mata

( ) mata ciliar

( ) pasto 
( ) plantio Especificar:

( ) outros. Qual?

9. Existem áreas de mata na propriedade? ( ) Sim ( ) Não

9.1 Para resposta afirmativa: ( ) Contínua ( ) Fragmentada

9.2 Tamanho:

9.3 Onde estão localizadas?

10. Quais dos seguintes animais silvestres são encontrados nas proximidades? Qual a primeira palavra que te vem na cabeça ao olhar estas figuras?
( ) jaguatirica
( ) tatu
( ) cateto
( ) guaxinim
( ) capivara
( ) tapiti
( ) cutia
( ) quati
( ) lontra

( )jaguarundi

( ) veado

( ) anta

( ) onça-pintada

( ) onça-parda

( ) cachorro-do-mato

( ) furão

Outros:

11. Indique sua atitude com relação aos seguintes animais silvestres:

\begin{tabular}{|c|c|c|c|c|c|c|}
\hline Animal & $\begin{array}{l}\text { Gosto } \\
\text { muito }\end{array}$ & Gosto & Indiferente & $\begin{array}{l}\text { Não } \\
\text { Gosto }\end{array}$ & Detesto & OBS. \\
\hline \multicolumn{7}{|c|}{$\begin{array}{l}\text { Animais } \\
\text { silvestres } \\
\text { geral }\end{array}$} \\
\hline \multicolumn{7}{|l|}{ Onças } \\
\hline \multicolumn{7}{|l|}{$\begin{array}{l}\text { Queixada } \\
\text { Cateto }\end{array}$} \\
\hline \multicolumn{7}{|l|}{$\begin{array}{l}\text { Jaguatirica } \\
\text { Jaguarundi } \\
\text { Gatos-do- } \\
\text { Mato }\end{array}$} \\
\hline \multicolumn{7}{|l|}{$\begin{array}{l}\text { Cachorro-do- } \\
\text { mato }\end{array}$} \\
\hline Guaxinim & & & & & & \\
\hline
\end{tabular}




\begin{tabular}{|l|l|l|l|l|l|l|}
\hline Animal & $\begin{array}{l}\text { Gosto } \\
\text { muito }\end{array}$ & Gosto & Indiferente & $\begin{array}{l}\text { Não } \\
\text { Gosto }\end{array}$ & Detesto & OBS. \\
\hline Veado & & & & & & \\
\hline Tatu & & & & & & \\
\hline Capivara & & & & & & \\
\hline
\end{tabular}

12. Qual o seu conhecimento sobre os seguintes animais:

\begin{tabular}{|l|l|l|l|}
\hline Espécie & $\begin{array}{l}\text { Solitário (S) } \\
\text { Pares (P) } \\
\text { Grupo (G) }\end{array}$ & $\begin{array}{l}\text { Carnívoro (C) } \\
\text { Herbivoro (H) } \\
\text { Frugivoro (F) } \\
\text { Onivoro (O) }\end{array}$ & $\begin{array}{l}\text { Foge do homem } \\
\text { (F) } \\
\text { Ataca (A) } \\
\text { Mata (M) }\end{array}$ \\
\hline Queixada & & & \\
\hline ICateto & & & \\
\hline Veado & & & \\
\hline Tatu & & & \\
\hline |Anta & & & \\
\hline Onça pintada/parda & & & \\
\hline Jaguatirica & & & \\
\hline Cachorro-do-mato & & & \\
\hline
\end{tabular}

13. Que tipos de plantio existem na propriedade?

\begin{tabular}{|c|l|}
\hline Plantio & Área Ocupada ( ha) \\
\hline Milho & \\
\hline Trigo & \\
\hline Soja & \\
\hline Feijão & \\
\hline Mate & \\
\hline Pastagem & \\
\hline Horta & \\
\hline Outra ( ). Qual? & \\
& \\
\end{tabular}

14. Nos últimos anos sua plantação já foi invadida por algum animal silvestre? ( ) Sim ( ) Não 
14.1 Para resposta afirmativa:

( ) Freqüente ( ) Ocasional ( ) Raro

\begin{tabular}{|l|l|l|c|c|c|}
\hline Mês/Ano & Plantação & Animal & $\begin{array}{c}\text { Área } \\
\text { Atingida }\end{array}$ & $\begin{array}{c}\text { Prejuízo } \\
\text { Estimado }\end{array}$ & $\begin{array}{c}\text { Prejuízo } \\
\text { Calculado }\end{array}$ \\
\hline & & & & & \\
\hline & & & & & \\
\hline
\end{tabular}

14.2 Como sabe que a predação ocorreu por animal silvestre?
( ) Viu
( ) Pelo tipo de dano
( ) Observou pegadas

( ) Outro vestigio. Qual?

15. Já procurou alguma instituição para ajudar a solucionar o problema de predação em plantios por animais silvestres?

( ) Sim ( ) Não

15.1 Para resposta negativa:

Por quê?

15.2 Para resposta afirmativa:

Qual?

( ) IBAMA

( ) Polícia Florestal

( ) Prefeitura

( ) IAP

( ) Secretaria da Agricultura

( ) EMATER

Outro. Qual?

16. Você acha que é preciso controlar a predação de plantações por animais silvestres?

( ) Sim ( ) Não

16.1 Para resposta negativa:

Por quê:

16.2 Para resposta afirmativa: Como? 
16.2.1 Quais dos seguintes métodos você acha mais apropriado?

( ) Não plantar próximo ao Parque

( ) Utilizar cerca

( ) Utilizar cerca elétrica

( ) Compensação financeira por perdas

( ) Remover os "animais problema"

( ) Exterminar as espécies que causam prejuizos

( ) Permitir a caça

( ) Utilizar iscas envenenadas

17. Que tipos de criações de animais domésticos existem na propriedade?

\begin{tabular}{|c|c|c|}
\hline Animal & Quantidade & $\begin{array}{c}\text { Tipo de Manejo } \\
\text { (C=Confinamento; E= } \\
\text { Extensivo; } \\
\text { E/C= extensivo } \\
\text { dia/confinamento noite) }\end{array}$ \\
\hline Porco & & \\
\hline Galinha & & \\
\hline Ovelha & & \\
\hline Cavalo & & \\
\hline Cabra & & \\
\hline Gado & & \\
( ) Leite & & \\
( ) Corte & & \\
\hline Outros. Quais? & & \\
\hline
\end{tabular}

18. Você protege a criação de animais silvestres?
( ) $\mathrm{Sim}$
( ) Não

18.1 Para resposta negativa:

Por quê: 
18.2 Para resposta afirmativa:

Como:

19. Nos últimos anos alguma criação foi atacada por animal silvestre?

( ) $\operatorname{Sim}$ ( ) Não

19.1 Para resposta afirmativa:

( ) Frequente ( ) Ocasional ( ) Raro

\begin{tabular}{|l|l|l|l|l|l|l|}
\hline Mês/Ano & Criação & $N^{\circ}$ & $\begin{array}{c}\text { Idade }(A= \\
\text { adulto; } \mathrm{J}= \\
\text { jovem; } \mathrm{R}=\text { recém } \\
\text { nascido)/ Sexo }\end{array}$ & Local & Predador & $\begin{array}{l}\text { Valor do } \\
\text { Prejuizo }\end{array}$ \\
\hline & & & & & & \\
\hline & & & & & & \\
\hline
\end{tabular}

20. Como sabe que a predação ocorreu por animal silvestre?

( ) Viu ( ) Pelo tipo de dano ( ) Observou pegadas

( ) Outro vestígio. Qual?

21. Sabe distinguir entre morte por predação e morte por doença, raios, acidente?

( ) Sim ( ) Não

21.1 Para resposta afirmativa:

Como distingue?

22. Já procurou alguma instituição para ajudar a solucionar o problema de predação sobre animais domésticos?
( ) Sim
( ) Não

22.1 Para resposta negativa:

Por quê?

22.2 Para resposta afirmativa:

Qual?
( ) IBAMA
( ) Polícia Florestal
( ) Prefeitura
( ) IAP
( ) Secretaria da Agricultura
( ) EMATER

Outro. Qual? 
23. Você acha que é preciso controlar a predação de animais domésticos por animais silvestres?

( ) Sim ( ) Não

23.1 Para resposta negativa:

Por quê:

23.2 Para resposta afirmativa: Como?

23.2.1 Quais dos seguintes métodos você acha mais apropriado?

( ) Evitar deixar os animais em áreas de risco ( por exemplo bordas de matas)

( ) Utilizar cerca

( ) Utilizar cerca elétrica

( ) Compensação financeira por perdas

( ) Remover os "animais problema"

( ) Exterminar as espécies que causam prejuízos

( ) Permitir a caça

( ) Utilizar iscas envenenadas

( ) Melhorar as práticas de manejo ( por exemplo: guardar rebanhos em piquetes mais próximos de casas; confinamento noturno; usar cães)

24. No caso de compensação financeira, tanto por danos em culturas quanto em criações, para qual porcentagem de perdas causadas por animais silvestres 0 fazendeiro deveria ser reembolsado?

( ) Não deve ser reembolsado

( ) até $25 \%$

( ) $26 \%-50 \%$

( ) mais de 50 
Apêndice 3 - Pontuação estabelecida para avaliar conhecimento sobre comportamento e hábitos alimentares de mamíferos silvestres.

\begin{tabular}{|c|c|c|c|}
\hline Espécie & $\begin{array}{l}\text { Solitário (S) } \\
\text { Pares (P) } \\
\text { Grupo (G) }\end{array}$ & $\begin{array}{l}\text { Carnívoro (C) } \\
\text { Herbivoro (H) } \\
\text { Frugivoro (F) } \\
\text { Onivoro (O) } \\
\text { Insetivoro (I) }\end{array}$ & $\begin{array}{l}\text { Foge do homem }(F) \\
\text { Ataca }(A)\end{array}$ \\
\hline Queixada & $\begin{array}{l}S=0 \\
P=0 \\
N a ̃ \text { sei }=1 \\
G=2\end{array}$ & $\begin{array}{l}\mathrm{C}=0 \\
\mathrm{O} / \mathrm{l}=0 \\
\mathrm{Não} \text { sei }=1 \\
\mathrm{H} / \mathrm{F}=2\end{array}$ & $\begin{array}{l}A=0 \\
N a ̃ o \text { sei }=1 \\
F=2\end{array}$ \\
\hline Cateto & $\begin{array}{l}S=0 \\
P=0 \\
N a ̃ o \text { sei }=1 \\
G=2\end{array}$ & $\begin{array}{l}\mathrm{C}=0 \\
\mathrm{O} / \mathrm{l}=0 \\
\mathrm{Não} \text { sei }=1 \\
\mathrm{H} / \mathrm{F}=2\end{array}$ & $\begin{array}{l}A=0 \\
\text { Não sei }=1 \\
F=2\end{array}$ \\
\hline Veado & $\begin{array}{l}\mathrm{G}=0 \\
P=0 \\
N a ̃ o \text { sei }=1 \\
S=2\end{array}$ & $\begin{array}{l}\mathrm{C}=0 \\
\mathrm{O} / \mathrm{I}=0 \\
\mathrm{Não} \text { sei }=1 \\
\mathrm{H} / \mathrm{F}=2\end{array}$ & $\begin{array}{l}A=0 \\
\text { Não sei }=1 \\
F=2\end{array}$ \\
\hline Tatu & $\begin{array}{l}G=0 \\
P=0 \\
N a ̃ o \text { sei }=1 \\
S=2\end{array}$ & $\begin{array}{l}\mathrm{C}=0 \\
\mathrm{H} / \mathrm{F}=0 \\
\text { Não sei }=1 \\
\mathrm{O} / \mathrm{l}=2\end{array}$ & $\begin{array}{l}A=0 \\
\text { Não sei }=1 \\
F=2\end{array}$ \\
\hline Anta & $\begin{array}{l}G=0 \\
P=0 \\
N a ̃ o \text { sei }=1 \\
S=2\end{array}$ & $\begin{array}{l}\mathrm{C}=0 \\
\mathrm{O} / \mathrm{I}=0 \\
\mathrm{Não} \text { sei }=1 \\
\mathrm{H} / \mathrm{F}=2\end{array}$ & $\begin{array}{l}A=0 \\
N a ̃ o \text { sei }=1 \\
F=2\end{array}$ \\
\hline $\begin{array}{l}\text { Onça } \\
\text { Pintada/parda }\end{array}$ & $\begin{array}{l}G=0 \\
P=0 \\
\text { Não sei }=1 \\
S=2\end{array}$ & $\begin{array}{l}\mathrm{H} / \mathrm{F}=0 \\
\mathrm{O} / \mathrm{I}=0 \\
\text { Não sei }=1 \\
\mathrm{C}=2\end{array}$ & $\begin{array}{l}A=0 \\
\text { Não sei }=1 \\
F=2\end{array}$ \\
\hline Jaguatirica & $\begin{array}{l}G=0 \\
P=0 \\
N a ̃ o \text { sei }=1 \\
S=2\end{array}$ & $\begin{array}{l}\mathrm{H} / \mathrm{F}=0 \\
\mathrm{O} / \mathrm{I}=0 \\
\mathrm{Não} \text { sei }=1 \\
\mathrm{C}=2\end{array}$ & $\begin{array}{l}A=0 \\
N a ̃ o \text { sei }=1 \\
F=2\end{array}$ \\
\hline Cachorro-do-mato & $\begin{array}{l}G=0 \\
P=0 \\
N a ̃ o \text { sei }=1 \\
S=2\end{array}$ & $\begin{array}{l}\mathrm{H}=0 \\
\mathrm{~F} / \mathrm{l}=0 \\
\mathrm{Não} \text { sei }=1 \\
\mathrm{O} / \mathrm{C}=2\end{array}$ & $\begin{array}{l}A=0 \\
\text { Não sei }=1 \\
F=2\end{array}$ \\
\hline
\end{tabular}


Apêndice 4 - Animais de criação e espécies de predadores por ordem decrescente de preferências, segundo proprietários do entorno do Parque Nacional do Iguaçu.

\begin{tabular}{ll}
\hline Criação & \multicolumn{1}{c}{ Espécie de Predador } \\
\hline & 1) Cachorro-do-mato \\
2) Jaguarundi \\
2) Gato-do-mato \\
3) Jaguatirica \\
4) Gambá \\
5) Irara \\
6) Furão \\
6) Guaxinim \\
6) Cachorro-doméstico \\
OVELHA & 1) Onça-parda \\
2) Onça-pintada \\
3) Cachorro-doméstico \\
CACHORRO & 1) Onça-pintada \\
2) Onça-parda \\
CAVALO & 1) Onça-parda \\
& 2) Onça-pintada \\
\hline
\end{tabular}


Apêndice 5 - Principais culturas e espécies de predadores por ordem descrescente de preferência, segundo proprietários do entorno do Parque Nacional do Iguaçu.

\begin{tabular}{ll}
\hline Cultivo & Espécie de Predador \\
\hline & 1) Queixada \\
& 2) Cateto \\
& 3) Capivara \\
& 3) Macaco-prego \\
& 3) Tatu \\
& 3) Veado \\
4) Quati & 4) Ratão-do-banhado \\
4ILHO & 4) Caca \\
& 4) Guaxinim \\
MANDIOCA & 1) Queixada \\
PASTO & 2) Tatu \\
AMENDOIM & 1) Veado \\
ARROZ & 2) Capivara \\
AVEIA & 1) Queixada \\
CANA-DE-AÇUCAR & 2) Furão \\
ABACAXI & 1) Capivara \\
MAMÃO & 1) Capivara \\
& 1) Cachorro-do-mato \\
& 1) Quati \\
& 1) Lebre-européia \\
&
\end{tabular}

